\title{
Partitioning and Surficial Segregation of Trace Elements in Iron Oxides in Hydrothermal Fluid Systems
}

\author{
Nikolay Smagunov (D), Vladimir Tauson D, Sergey Lipko*(D), Dmitriy Babkin, Taisa Pastushkova, Olga Belozerova \\ and Nikolay Bryansky
}

check for

updates

Citation: Smagunov, N.; Tauson, V.; Lipko, S.; Babkin, D.; Pastushkova, T.; Belozerova, O.; Bryansky, N.

Partitioning and Surficial Segregation of Trace Elements in Iron Oxides in Hydrothermal Fluid Systems. Minerals 2021, 11, 57. https:// doi.org/10.3390/min11010057

Received: 29 October 2020 Accepted: 7 January 2021

Published: 10 January 2021

Publisher's Note: MDPI stays neutral with regard to jurisdictional clai$\mathrm{ms}$ in published maps and institutional affiliations.

Copyright: $(\odot 2021$ by the authors. Licensee MDPI, Basel, Switzerland. This article is an open access article distributed under the terms and conditions of the Creative Commons Attribution (CC BY) license (https:// creativecommons.org/licenses/by/ $4.0 /)$.
A.P. Vinogradov Institute of Geochemistry, Siberian Branch of Russian Academy of Science, 664033 Irkutsk, Russia; nicksm@igc.irk.ru (N.S.); vltauson@igc.irk.ru (V.T.); dimit172@mail.ru (D.B.); tais314@yandex.ru (T.P.); obel@igc.irk.ru (O.B.); tridigron@yandex.ru (N.B.)

* Correspondence: slipko@yandex.ru; Tel.: +7-3952-42-99-67

Abstract: Partitioning experiments were done by hydrothermal synthesis of crystals containing trace elements (TEs) by internal sampling of fluid at the temperature of $450{ }^{\circ} \mathrm{C}$ and pressure of $1 \mathrm{kbar}$. The crystal phases obtained were magnetite, hematite, and Ni-spinel, which were studied using X-ray diffraction (XRD), X-ray electron probe microanalysis (EPMA), laser ablation inductively coupled plasma mass spectrometry (LA-ICP-MS), atomic absorption spectrometry (AAS), and atomic force microscopy (AFM). The solutions from the sampler's fluid probes were analysed by AAS for TEs included elements of the iron group plus aluminium. The highest co-crystallisation coefficients of $\mathrm{TE}$ and Fe between mineral and fluid $\left(\mathrm{D}_{\mathrm{TE} / \mathrm{Fe}}\right)$ in magnetite were measured for $\mathrm{V}, \mathrm{Al}, \mathrm{Ni}$ and $\mathrm{Cr}$ (in decreasing order of $n$ units in value), a lower value was observed for Co $\left(2 \times 10^{-1}\right)$, and still lower values for $\mathrm{Ti}, \mathrm{Zn}$, and $\mathrm{Mn}\left(n \times 10^{-2}-10^{-3}\right)$. In hematite, $\mathrm{D}_{\mathrm{TE} / \mathrm{Fe}}$ values were highest for $\mathrm{Al}$ and $\mathrm{V}$ (order of $n$ units in value), while lower values characterised $\mathrm{Ti}, \mathrm{Cr}$, and $\mathrm{Co}\left(n \times 10^{-1}-10^{-3}\right)$, and the lowest values were exhibited by $\mathrm{Cu}, \mathrm{Mn}$, and $\mathrm{Zn}\left(n \times 10^{-5}\right)$. Copper was confirmed to be the most incompatible with all minerals studied; however, $\mathrm{Cu}$ had a high content on crystal surfaces. This surficial segregation contributes to the average TE concentration even when a thin layer of nonautonomous phase (NAP) is enriched in the element of interest. The accumulation of TEs on the surface of crystals increased bulk content 1-2 orders of magnitude above the content of structurally-bound elements even in coarse crystals. The inverse problem-evaluation of TE/Fe ratios in fluids involved in the formation of magnetite-containing deposits-revealed that the most abundant metals in fluids were Fe followed by $\mathrm{Mn}, \mathrm{Zn}$, and $\mathrm{Cu}$, which comprised 10 to $30 \%$ of the total iron content.

Keywords: iron group elements; aluminium; hydrothermal solution; co-crystallisation coefficient; magnetite; hematite; Ni-spinel; fluid composition; crystal surface; trace element surficial accumulation

\section{Introduction}

Quantitative data on the partitioning of trace elements (TE) constrain the composition of the minerals that crystallise from melts and hydrothermal fluids. Such data are important for the interpretation of mineral genesis-magmatic, sedimentary, hydrothermal, or metamorphic - and validation of hypotheses of primary mineral re-equilibration by post-crystallisation processes involving the action of meteoric water and/or hydrothermal fluids.

Magnetite is considered "an ideal indicator mineral" [1] due to its stability, wide variation in composition and high density allowing it to be separated from sediment components. Moreover, magnetite is a common and widespread mineral that can form in different types of rocks and physicochemical conditions [2]. It is well known that the composition of magnetite is highly susceptible to the parameters controlling mineral formation and alteration ([3] and references therein). The elements concentrations in 
magnetite, their ratios and covariations are widely used to distinguish magnetite of igneous or hydrothermal origin and discriminate between different types of deposits [4-6]. It is a simple matter to increase the number of examples known from the literature to support the significance of magnetite (and more rarely hematite $[7,8]$ ) as an important and sensitive petrogenetic indicator applicable not only in theoretical aspects of ore formation but also in practical aspects [9-15].

Hematite $\left(\alpha-\mathrm{Fe}_{2} \mathrm{O}_{3}\right)$ is a characteristic component of epigenetic environments. It often accompanies magnetite and participates in the redistribution of TEs. As magnetite oxidises, it can be replaced by hematite, but it is not always easy to recognise the relationship between these two minerals. It is often assumed that similar TE contents indicate that the minerals were derived from the same ore fluid [12]; however, this assumption may be incorrect if the distribution and co-crystallisation coefficients of TEs in the mineral-fluid system differ for magnetite and hematite. These characteristics are unknown for most TEs specific to iron oxides, so the purpose of this research was to fill this gap in data and define any differences between magnetite and hematite in the partitioning of common TEs in mineral-fluid systems.

Little is known about the behaviour of TEs in geochemical processes that leads to the correlations observed in natural magnetite and other spinel-type crystals. The problem is solvable due to advancements in analytical methods such as electron probe microanalysis (EPMA), laser ablation inductively coupled plasma mass spectrometry (LA-ICP-MS), and secondary ion mass spectrometry (SIMS), which allow for the study of the distribution of TEs at low concentrations; however, rarely were these data used to reconstruct the composition of the mineral-forming fluids. With respect to magnetite, attempts to reconstruct the composition of source fluids were undertaken for $\mathrm{Mn}, \mathrm{Cu}$, and $\mathrm{Zn}[1,15]$ on the basis of previous experimental work [16]. Even in these limited cases, several problems remain unsolved, such as the reason for high and variable concentrations of $\mathrm{Cu}$ in hydrothermal magnetite which "remain suspect and enigmatic" [1] and disagreement (by several orders of magnitude) between Mn-Fe exchange coefficients calculated thermodynamically and extrapolated from experimental data [16]. The applications of a large base of analytical data on the content of TEs found in iron oxides to identify the TE ratios in hydrothermal fluids were limited. This is due to the lack of reliable quantitative data on the TE partition coefficients $\left(D_{p}^{\min / f l}=C_{T E}^{\min } / C_{T E}^{f l}\right)$ and co-crystallisation coefficients $\left(D_{T E / F e}^{\min / f l}=C_{T E}^{\min } / C_{F e}^{m i n} \times C_{F e}^{f l} / C_{T E}^{f l}\right)$ in magnetite (and hematite) in hydrothermal fluid systems. Here $C$ is the concentration; min and $f l$ denote mineral and fluid, accordingly. The purpose of the work presented herein was to reduce this deficiency by adding new data.

Another problem discussed here is surficial segregation of TEs and their effect on the partitioning of elements. The extent of surface accumulation of the REEs Ce, Eu, Er, and $\mathrm{Yb}$ was more than two orders of magnitude greater in the outermost layer of magnetite and hematite crystals obtained from an experimental hydrothermal system at $450{ }^{\circ} \mathrm{C}$ and $100 \mathrm{MPa}$ pressure [17]. X-ray photoelectron spectroscopy (XPS) revealed an oxyhydroxide composition for the surficial nonautonomous phase (NAP) that accumulated the REEs, with ratios of $\mathrm{Fe}^{3+} / \mathrm{Fe}^{2+}$ of 1.1 for both minerals, while the ratio of $\mathrm{O}^{2-} / \mathrm{OH}^{-}$was 1.5 for magnetite and approximately 4 for hematite [17]. The tendency for TEs to accumulate near the surface of magnetite particles was reported for $\mathrm{Cu}, \mathrm{Mn}$, and $\mathrm{Cd}$ [18]. The surface enrichment of hydrothermal magnetite with TEs is possibly due to the accumulation of TE-containing nanoparticles (NPs) formed from supersaturated hydrothermal fluids by the mechanism of entrapment as the surface of magnetite crystals grow [19]. The interfacial fluid also plays an active role in the formation of supersaturated TEs in solid solution during crystal growth and was proposed as a mechanism to explain the formation of Al-rich lamellae and zinc spinel NPs in the host magnetite [20]. The effect of surface accumulation and segregation of TEs is important in the interpretation of experimental and analytical data, especially data obtained using bulk analytical techniques on small particles with high specific surface area. 


\section{Background}

Under the crystallisation of isomorphous mixture (BE,TE) $\mathrm{X}$, where $\mathrm{X}$ is an anion, $\mathrm{TE}$ is a trace (or minor) element and $\mathrm{BE}$-basic element cation of the mineral, the exchange reaction $B E^{s}+T E^{a q}=T E^{s}+B E^{a q}$ occurs where $s$ and $a q$ denote solid and aqueous (fluid) phases, accordingly. The effective bulk coefficient of TE and BE co-crystallisation is

$$
D_{T E / B E}=\left(C_{T E} / C_{B E}\right)^{s} \times\left(C_{B E} / C_{T E}\right)^{a q},
$$

where $C$ is the concentration of the element. Hereinafter we deal only with bulk contents of elements rather than with their concentrations in various chemical forms (complexes). Strictly speaking, the process of co-crystallisation depends on the activities rather than concentrations and the bulk co-crystallisation coefficient is not a true constant but dependent on the composition of aqueous and solid phases. However, according to the model of complex solvent, for which the bulk electrolyte dominates over precipitated components, the expression is valid

$$
D_{T E / B E}=D_{T E / B E}^{o} \times F_{B E} / F_{T E} \times f_{B E X} / f_{T E X} .
$$

Here $D_{T E / B E}^{o}$ is the "ideal" coefficient dependent only on the solubilities of the pure phases-solid solution end members, $F$ is a Fronius function of the element complexation in aqueous solution, and $f$ is the activity coefficient of the component in solid solution [21]. $D_{T E / B E}^{o}$ is the thermodynamic constant of the interphase ion exchange reaction independent of the presence of other components and phases in the system. It is proportional to the ratio of the activity products $L_{\mathrm{TEX}} / L_{\mathrm{BEX}}$, which is related to solubilities (S) of TEX and BEX:

$$
D_{T E / B E}^{o}=S_{T E X}^{2} / S_{B E X}^{2}=L_{T E X} / L_{B E X} \times F_{T E} / F_{B E} .
$$

$F$ and $f$ ratios in Equation (2) are often invariable for the elements, which are chemically similar and demonstrate the same chemical behaviour in the same solution [21-23].

The theoretical considerations were proved by studying the hydrothermal crystallization of sulphide minerals (galena, sphalerite) in presence of admixtures of $\mathrm{Cd}, \mathrm{Mn}$ and Fe $[22,24,25]$. The experiments in the PbS-CdS-hydrothermal fluid system at the temperature of $300-430^{\circ} \mathrm{C}$ and pressure of $1 \mathrm{kbar}$ confirmed the obtained relations between bulk coefficient of co-crystallisation and solubilities of end members PbS and CdS [24]. The stability of this coefficient under various physicochemical conditions was demonstrated as well as the possibility of estimation of natural fluid composition using the co-crystallisation coefficients. These conclusions were supported by the example of $\mathrm{Mn}$ and Fe co-crystallisation with sphalerite in various mineralizing solutions at 400 and $500{ }^{\circ} \mathrm{C}$ and 1 and 1.5 kbar [22]. Stability of the $D_{\mathrm{Mn} / \mathrm{Fe}}$ value allowed the proposal that the bulk co-crystallisation coefficient under the conditions of natural hydrothermal process does not vary significantly in a wide range of variations of physicochemical parameters and solution compositions.

With respect to the iron oxide minerals, the data on TE co-crystallisation under hydrothermal conditions are severely limited [16,26,27].

The main purpose of this work is to obtain the data on partitioning of the main TE of magnetite and hematite, estimate $D_{\mathrm{TE} / \mathrm{Fe}}$ values and give geochemical implications allowing mineral's composition to be used as a quantitative indicator of TE concentration in ore-forming fluids. The acquisition of reliable data on elements' distribution in the mineral-hydrothermal fluid system suggests that the effect of surficial TE accumulation is taken into account, and this effect is also considered in the present paper.

\section{Materials and Methods}

\subsection{Experimental Procedure}

Standard techniques of hydrothermal thermogradient synthesis of iron oxides in presence of the TE were applied using stainless steel $\left(200 \mathrm{~cm}^{3}\right)$ autoclaves equipped with 
titanium alloy (VT-8) passivated inserts with a volume of $\sim 50 \mathrm{~cm}^{3}$ each. An internal sampling method using perforated titanium traps was used to obtain data on the composition of the high-temperature fluid phase [17]. The temperature in the zone of crystal growth was $450{ }^{\circ} \mathrm{C}$ and the pressure was $1 \mathrm{kbar}$. These values of temperature and pressure were high enough for near-equilibrium crystal growth and for trapping fluid in quantities required for analysis [28]. The liquid-to-solid ratio in the experiments was $\sim 5$. The full duration of the experiments was 24 days with the first 4 days under an isothermal regime applied to homogenise the batch material and ensure near-equilibrium conditions for the subsequent 20 days of thermogradient recrystallisation with a temperature drop of $15^{\circ} \mathrm{C}$ on the exterior wall of the autoclave. The actual temperature gradient inside the reaction vessel for this configuration was no more than $0.1{ }^{\circ} \mathrm{C} / \mathrm{cm}$ [29]. The experiments were terminated by autoclave quenching under cold running water with a temperature drop of $5{ }^{\circ} \mathrm{C} / \mathrm{s}$. After insert unsealing, the solution was immediately extracted from the sampler which was rinsed with aqua regia to dissolve any remaining precipitates. The cleaning solution was subsequently combined with the first solution extracted, and a special chemical medium was created to analyse the elements using atomic absorption spectrometry (AAS). The conditions were not equal in different experiments and we did not attempt in this work to estimate the reproducibility of data in a parallel experiment. However, according to our experience with $\mathrm{Au}$, the reproducibility of trapped fluid composition for trace elements is better than 30 rel.\% [30]. pH measured in the solutions from samplers varied over the range of 7.2-8.1. The occurrence of fine-grained hematite as a quench phase (see below) suggests that the experimental conditions were close to the magnetite-hematite equilibrium ( $\log f \mathrm{O}_{2}=-21.6 \mathrm{bar}$ ). The batch was made up of high purity reagents (pure reagent-grade) and comprising two parts. The basic components were represented by oxidised $\left(\mathrm{Fe}_{2} \mathrm{O}_{3}\right)$ and reduced ( $\mathrm{FeO}$ or metallic $\mathrm{Fe}$ ) forms of iron in a molar ratio of 1 or 2 , or solely in the oxidised form. The TEs were introduced to the batch as metal oxides (Table 1). The Fe component of the batch weighed $5 \mathrm{~g}$, and each TE oxide were 0.1 or $0.25 \mathrm{wt} \%$ of batch weight. The significant part of the batch ( 10-30\%) was left after the experiments. The crystals formed in the upper part of the insert yielded up to $600 \mathrm{mg}$. Solutions of ammonium chloride $\left(\mathrm{NH}_{4} \mathrm{Cl}\right)$ of 5 and $10 \%$ were reported to be the most effective mineralising solutions for growing iron oxide crystals [17]. This solute is also significant for natural fluid systems [24,31,32].

\subsection{Analytical Methods}

\subsubsection{X-ray Electron Probe Microanalysis (EPMA)}

Iron oxide crystals of magnetite, hematite, and Ni-spinel were inserted into wellpolished epoxy pellets after they were washed with distilled water and ethanol and analysed using EPMA with a Superprobe JXA-8200 (JEOL Ltd., Tokyo, Japan) microprobe supplied with energy dispersive and wavelength-dispersive spectrometers (WDS) in Vinogradov Institute of Geochemistry of SB RAS (Irkutsk, Russia). Quantitative WDS analyses were conducted at an accelerating voltage of $20 \mathrm{kV}$, a beam current of $20 \mathrm{nA}$, a beam diameter of $1 \mu \mathrm{m}$, and a counting time of $10 \mathrm{~s}$ for major elements and $20 \mathrm{~s}$ or $30 \mathrm{~s}$ for TEs. The background counts were $5 \mathrm{~s}$ or $10 \mathrm{~s}$ long for major elements and $15 \mathrm{~s}$ long for TEs. Matrix corrections and analysed element contents were calculated using the ZAF (atomic number, absorption, and fluorescence) approach applying the software for quantitative analysis for Superprobe JXA-8200 (V01.42@ 2021-2007, JEOL Ltd., Tokyo, Japan). Standardisation was performed using well-characterised minerals (hematite $\mathrm{Fe}_{2} \mathrm{O}_{3}$ for $\mathrm{Fe}$, spinel $\mathrm{MgAl}_{2} \mathrm{O}_{4}$ for $\mathrm{Al}$, chalcopyrite $\mathrm{CuFeS}_{2}$ for $\mathrm{Cu}$, sphalerite $\mathrm{ZnS}$ for $\mathrm{Zn}$, and rutile $\mathrm{TiO}_{2}$ for Ti), alloys (FeNiCo for Ni and $\mathrm{Co}$ ) and oxides $\left(\mathrm{V}_{2} \mathrm{O}_{5}\right.$ for $\mathrm{V}, \mathrm{Cr}_{2} \mathrm{O}_{3}$ for $\mathrm{Cr}$, and $\mathrm{MnO}$ for $\mathrm{Mn}$ ) as standard samples. Measurements were made at 10 to 20 points on each grain, depending on its homogeneity. Reliable estimates of the TE content by EPMA was possible for $\mathrm{Co}, \mathrm{Ni}, \mathrm{Al}$, $\mathrm{V}$, and $\mathrm{Mn}$ (the minimum detection limit (MDL) $\approx 0.1 \mathrm{wt} \%$ ). TE concentrations and their standard deviations are presented in Appendix A (Table A1). 
Table 1. Conditions and results of hydrothermal experiments on synthesis of iron oxide phases with trace elements at $450{ }^{\circ} \mathrm{C}$ and $1 \mathrm{kbar}$.

\begin{tabular}{|c|c|c|c|c|c|c|c|c|c|c|c|c|c|c|c|}
\hline \multirow{3}{*}{$\begin{array}{l}\text { Experi- } \\
\text { ment No. }\end{array}$} & \multicolumn{12}{|c|}{ Batch Composition } & \multirow{3}{*}{$\begin{array}{l}\mathrm{NH}_{4} \mathrm{Cl} \\
\text { in So- } \\
\text { lution } \\
(\mathrm{wt} \%)\end{array}$} & \multicolumn{2}{|c|}{ Experiment Products } \\
\hline & \multicolumn{3}{|c|}{ Basic Components $^{a}$} & \multicolumn{9}{|c|}{ Trace Element Oxides (wt $\%)$} & & & \\
\hline & $\mathrm{Fe}_{\mathrm{ox}} / \mathrm{Fe}_{\text {red }}$ & $\begin{array}{c}\mathrm{Fe}_{o x} \\
\left(w t_{0}\right)\end{array}$ & $\begin{array}{c}\mathrm{Fe}_{\text {red }} \\
(w t \%)\end{array}$ & $\mathrm{Al}_{2} \mathrm{O}_{3}$ & $\mathrm{TiO}_{2}$ & $\mathrm{CoO}$ & $\mathrm{NiO}$ & $\mathrm{CuO}$ & $\mathrm{ZnO}$ & $\mathrm{Mn}_{2} \mathrm{O}_{3}$ & $\mathrm{~V}_{2} \mathrm{O}_{3}$ & $\mathrm{Cr}_{2} \mathrm{O}_{3}$ & & Obtained $^{b}$ & $\begin{array}{c}\text { Trapped } \\
\text { Fluid (wt } \%)\end{array}$ \\
\hline 1 & 1 & 68.57 & 30.83 & 0.1 & 0.1 & 0.1 & 0.1 & 0.1 & 0.1 & - & - & - & 5 & Mt & 0.994 \\
\hline 2 & 2 & 84.61 & $(14.79)$ & 0.1 & 0.1 & 0.1 & 0.1 & 0.1 & 0.1 & - & - & - & 5 & Mt & 1.337 \\
\hline 3 & 1 & 67.95 & 30.55 & 0.25 & 0.25 & 0.25 & 0.25 & 0.25 & 0.25 & - & - & - & 5 & Mt & 0.085 \\
\hline 4 & 2 & 83.84 & $(14.66)$ & 0.25 & 0.25 & 0.25 & 0.25 & 0.25 & 0.25 & - & - & - & 5 & $\mathrm{Ni}-\mathrm{Sp}$ & 1.929 \\
\hline $5^{c}$ & 1 & 67.95 & 30.55 & 0.25 & 0.25 & 0.25 & 0.25 & 0.25 & 0.25 & - & - & - & 10 & $\mathrm{Mt}^{\mathrm{T}}$ & 0.286 \\
\hline 6 & 2 & 83.84 & (14.66) & 0.25 & 0.25 & 0.25 & 0.25 & 0.25 & 0.25 & - & - & - & 10 & $\mathrm{Ni}-\mathrm{Sp}$ & 0.637 \\
\hline $7^{c}$ & 2 & 81.15 & 18.25 & 0.1 & 0.1 & 0.1 & 0.1 & 0.1 & 0.1 & - & - & - & 5 & $\mathrm{Mt}$ & 3.812 \\
\hline $8^{c}$ & 2 & 80.42 & 18.08 & 0.25 & 0.25 & 0.25 & 0.25 & 0.25 & 0.25 & - & - & - & 5 & Mt & 1.686 \\
\hline $9^{c}$ & 2 & 80.42 & 18.08 & 0.25 & 0.25 & 0.25 & 0.25 & 0.25 & 0.25 & - & - & - & 10 & $\mathrm{Hm}$ & 2.569 \\
\hline 10 & $\begin{array}{l}\mathrm{Fe}_{\mathrm{ox}} \\
\text { only }\end{array}$ & 99.1 & 0 & 0.1 & 0.1 & 0.1 & 0.1 & 0.1 & 0.1 & 0.1 & 0.1 & 0.1 & 5 & $\mathrm{Mt}+\mathrm{Hm}$ & 0.968 \\
\hline 11 & same & 97.75 & 0 & 0.25 & 0.25 & 0.25 & 0.25 & 0.25 & 0.25 & 0.25 & 0.25 & 0.25 & 10 & $\mathrm{Mt}+\mathrm{Hm}$ & 0.233 \\
\hline 12 & same & 99.1 & 0 & 0.1 & 0.1 & 0.1 & 0.1 & 0.1 & 0.1 & 0.1 & 0.1 & 0.1 & 10 & $\mathrm{Hm}$ & 0.380 \\
\hline
\end{tabular}

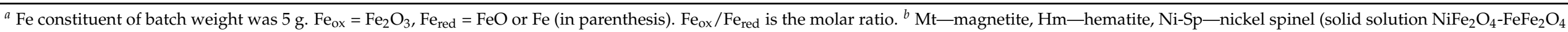
close to $\mathrm{Ni}$ end member). ${ }^{c}$ Small quantities of potassium dichromate were added to improve growth of Fe oxide crystals [17]. Dash denotes that the component was not added to the batch. 


\subsubsection{X-ray Diffraction (XRD)}

XRD was used mainly for phase analysis and to recognize the phase composition of the minerals produced in the experiments (magnetite, hematite, magnetite + hematite, and $\mathrm{Ni}$-spinel) employing powder diffraction patterns. Unit cell edges were measured with a D8 ADVANCE diffractometer (Bruker, Germany) using $\mathrm{CuK} \alpha$ radiation in Vinogradov Institute of Geochemistry of SB RAS. Phases were identified using a base of powder diffraction data PDF-2 (ICCD PDF-2, Release 2007). Phase composition and unit cell edges were refined using the program TOPAS 4 (User's Manual, Bruker AXS, 2008, Karlsruhe, Germany). Uncertainties in unit cell edges occurred at the level of $\pm 1-3 \times 10^{-4} \mathrm{~nm}$; sensitivity to the presence of admixed phases was $0.5 \mathrm{wt} \%$.

\subsubsection{Atomic Absorption Spectrometry (AAS)}

The AAS method was used to analyse trapped solutions [17,26,27]. As a bulk method, AAS played a supporting role to EPMA and LA-ICP-MS in the study of the solid phases obtained because of the phenomenon of surficial TE accumulation [17]. AAS measurements were performed on Perkin-Elmer instruments (Model 403 and Analyst 800, The Perkin Elmer Corp., Norwalk, CT, USA) in the Vinogradov Institute of Geochemistry of SB RAS. Elements were determined with a precision of $\pm 5-10$ rel.\%. Element concentrations were calculated by external calibration using standard solutions prepared in-house from analytically pure substances.

\subsubsection{Laser Ablation Inductively Coupled Plasma Mass Spectrometry (LA-ICP-MS)}

(1) Bulk Crystals

For this analysis, we used the same crystals mounted in epoxy pellets that were analysed by EPMA. Measurements were performed on an Agilent 7500ce unit manufactured by Agilent Technologies with quadrupole mass analyser (Agilent Tech., Santa Clara, CA, USA) using a New Wave Research UP-213 laser ablation platform in the Limnological Institute of SB RAS (Irkutsk, Russia). Parameters of the LA-ICP-MS experiment were: plasma power of $1400 \mathrm{~W}$, carrier gas flow rate of $1 \mathrm{~L} / \mathrm{min}$, plasma-forming gas flow rate of $15 \mathrm{~L} / \mathrm{min}$, cooling gas at $1 \mathrm{~L} / \mathrm{min}$, laser energy at $80 \%$, frequency of $10 \mathrm{~Hz}$, and a laser spot diameter of $55 \mu \mathrm{m}$. Dwell times per isotope/element were $0.15 \mathrm{~s}$, and acquisition time was $14 \mathrm{~s}$. Measurements were made at 15 to 16 points in several ( 3 to 4 ) grains from each sample. The content of $\mathrm{Ni}$ and Co was determined by EPMA in each grain of each sample analysed and used as internal standards. Due to high content in iron oxides, Fe is less sensitive to composition variations and less convenient as an element used for studying correlation of LA-ICP-MS and EPMA data when the local areas of crystals are analysed.

Calculations of TE concentrations were based on standard samples NIST 610 and NIST 612 which were well suited for this analysis and produced reliable results when measuring TE concentrations in magnetite on the order of ppm to sub-ppm [14]. Standard deviations are given in Table A1. MDLs ( $3 \times$ the standard deviation of the blank) were estimated as follows $(\mu \mathrm{g} / \mathrm{g}):{ }^{60} \mathrm{Ni}=0.26,{ }^{59} \mathrm{Co}=0.25,{ }^{63} \mathrm{Cu}=0.22,{ }^{51} \mathrm{~V}=0.24,{ }^{55} \mathrm{Mn}=0.28,{ }^{66} \mathrm{Zn}=1.1$, ${ }^{27} \mathrm{Al}=1.8,{ }^{47} \mathrm{Ti}=2.9$, and ${ }^{52} \mathrm{Cr}=3.1$.

(2) Outermost Crystal Layers

Only crystals of high quality with smooth faces were used to study TE distribution in the outermost layers by sequential laser removal in combination with ICP-MS analysis performed in the Vinogradov Institute of Geochemistry of SB RAS (see [33] for details). The requirements for the unpolished crystals studied were fulfilled exactly for magnetite crystals, while hematite crystals were often smooth-faced but the face areas were not large enough to analyse. The instrument system involved a quadrupole mass-spectrometer (Perkin Elmer NexION 300D) and a laser ablation platform (NWR-213). Plasma power was $1400 \mathrm{~W}$, the carrier gas was Ar delivered at a rate of $0.8 \mathrm{~L} / \mathrm{min}$, and the rates of the auxiliary flows (plasma/cool and auxiliary gas) were 18 and $1 \mathrm{~L} / \mathrm{min}$, respectively. Due to the high scan rate, 63 scans per minute were recorded which allowed us to clearly discriminate variations in material flux with time. The YAG:Nd laser platform (wavelength $=213 \mathrm{~nm}$ ) 
was optimised for aerosol transportation using pure He over the shortest distance to the mass spectrometer torch at a flow rate of $0.6 \mathrm{~L} / \mathrm{min}$. Laser power was set at $20 \%$, frequency at $10 \mathrm{~Hz}$, and laser spot diameter at $100 \mu \mathrm{m}$. The laser beam passed along a straight-line profile of each sample six times at a rate of $200 \mu \mathrm{m} / \mathrm{s}$, so that the first and last spots occurred outside of the sample. Inasmuch as the end points of the profiles were outside the sample, we were able to clearly distinguish between the mass spectrometry data of all six ablation passes on each sample and eliminate the effect of deep laser ablation of the material at the beginning of the profiles because of the extra time needed to accurately position the platform. The calibration of elements to be analysed was carried out using the NIST 612 standard conformed to the in-house standard sample-highly homogeneous magnetite crystals synthesised hydrothermally. Unfortunately, it proved difficult to standardise the depth due to high surface roughness along the laser track and material sputtering along the ablation groove, thus the data obtained were rated as semiquantitative. However, the data obtained in [33] for hydrothermal magnetite crystal surface under similar conditions of analysis allowed us to estimate the depth of groove after one laser pass as $\sim 1.5 \mu \mathrm{m}$.

\subsubsection{Atomic Force Microscopy (AFM)}

The surface morphology of the crystals was investigated in contact mode with an SMM-2000 scanning multi-microscope (Zelenograd, Russia) in Vinogradov Institute of Geochemistry of SB RAS. The microscope's software made it possible to analyse roughness and other surface characteristics and determine the height and shape of nano-sized objects on the crystal surfaces. Standard $\mathrm{Si}_{3} \mathrm{~N}_{4}$ cantilevers (Veeco, Park Scientific, USA) with a tip-rounding radius of $10 \mathrm{~nm}$ were used. The SMM-2000 microscope was a certified measurement tool (no. 980080025). According to the certificate, the maximum resolution was $2.5 \mathrm{~nm}$ in the $\mathrm{X}-\mathrm{Y}$ plane and $1.1 \mathrm{~nm}$ in the $\mathrm{Z}$ direction.

\section{Results}

\subsection{Characteristics of Phases Obtained}

Sufficiently large crystals (up to $3 \mathrm{~mm}$ ) of magnetite and smaller crystals (up to $1 \mathrm{~mm}$ ) of Ni-spinel and hematite were obtained. In two experiments, magnetite and hematite were obtained together (Table 1). Magnetite crystals were usually octahedral (Figure 1), Ni-spinel demonstrated better development of $\{110\}$ and $\{100\}$ faces combined with $\{111\}$, and hematite crystals formed hexagonal prisms combined with well-developed pyramids of different indexes and usually assembled into compact-grained aggregates (Figure 2). TE oxides were not found in crystals as well as in the residual dispersed batch material. The quench phase was mainly the bricky-colour hematite crystals and aggregates of $\sim 10-40 \mu \mathrm{m}$ in size. The patches of quench phase were rarely observed on the surface of single crystals obtained because the solution was isolated from growth zone under quenching below $\sim 380^{\circ} \mathrm{C}$, a critical point of $\mathrm{NH}_{4} \mathrm{Cl}$ solution.
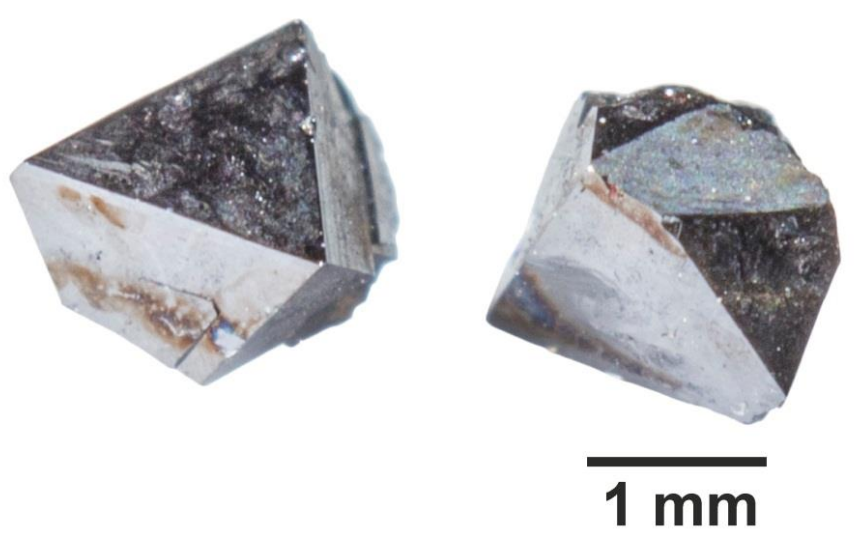

Figure 1. Crystals of magnetite synthesised (conditions $-450{ }^{\circ} \mathrm{C}, 1 \mathrm{kbar}, \mathrm{NH}_{4} \mathrm{Cl}$ solution) displaying prevailing crystal habit. 


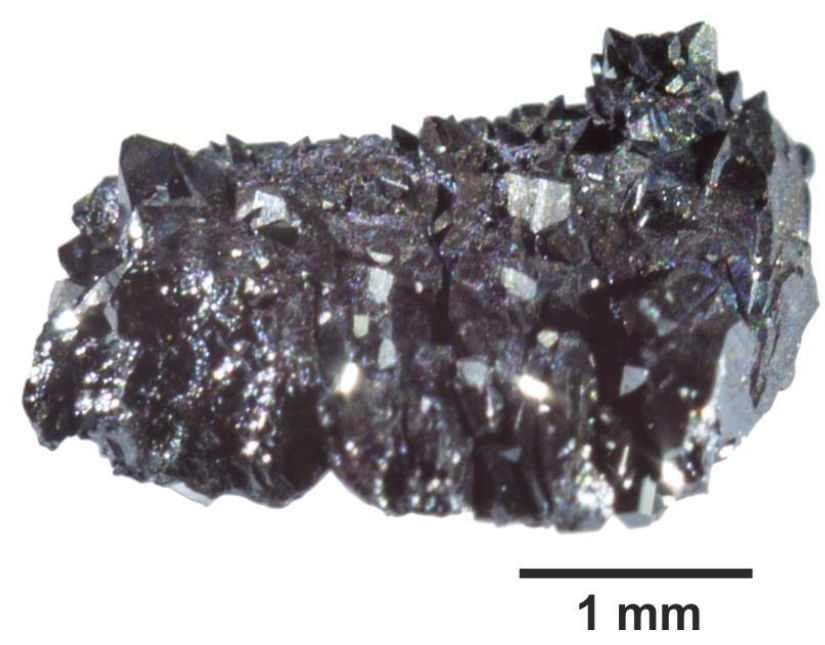

Figure 2. Crystalline hematite aggregate synthesized (conditions- $450{ }^{\circ} \mathrm{C}, 1 \mathrm{kbar}, \mathrm{NH}_{4} \mathrm{Cl}$ solution).

The unit cell edges of the phases obtained were $(\mathrm{nm})$ : magnetite, $a=0.8393-0.8396 \mathrm{~nm}$, Ni-spinel, $a=0.8353-0.8360 \mathrm{~nm}$, and hematite, $a=0.5031-0.5032 \mathrm{~nm}$ and $c=1.3710-1.3746$ $\mathrm{nm}$. The composition of Ni-spinel was calculated from EPMA data (Table A1, Experiments Nos. 4 and 6) using the formulas: $\mathrm{Fe}^{3+}\left[\mathrm{Fe}_{1.04}^{3+} \mathrm{Fe}_{0.03}^{2+} \mathrm{Ni}_{0.88}^{2+} \mathrm{Co}_{0.03}^{2+}\right]_{1.98} \mathrm{O}_{4}$ (Experiment No. 4) and $\mathrm{Fe}^{3+}\left[\mathrm{Fe}_{1.06}^{3+} \mathrm{Fe}_{0.20}^{2+} \mathrm{Ni}_{0.67}^{2+} \mathrm{Co}_{0.04}^{2+}\right]_{1.97} \mathrm{O}_{4}$ (Experiment No. 6) to account for the presence of $\mathrm{Ni}$ or $\mathrm{Co}$ in the octahedral sites of the magnetite (inverse spinel) structure in a bivalent state [34]. The content of other TEs was negligible ( $\leq 0.1$ at.\%); therefore, both phases are solid solutions of magnetite and trevorite $\left(\mathrm{NiFe}_{2} \mathrm{O}_{4}\right)$ close to the $\mathrm{Ni}$ end-member.

EPMA showed essential homogeneity of the interiors of magnetite crystals (Figure 3). Hematite crystals often manifested the growth zonality (Figure 4), and this was a possible reason for wider variations of TE contents in this phase.

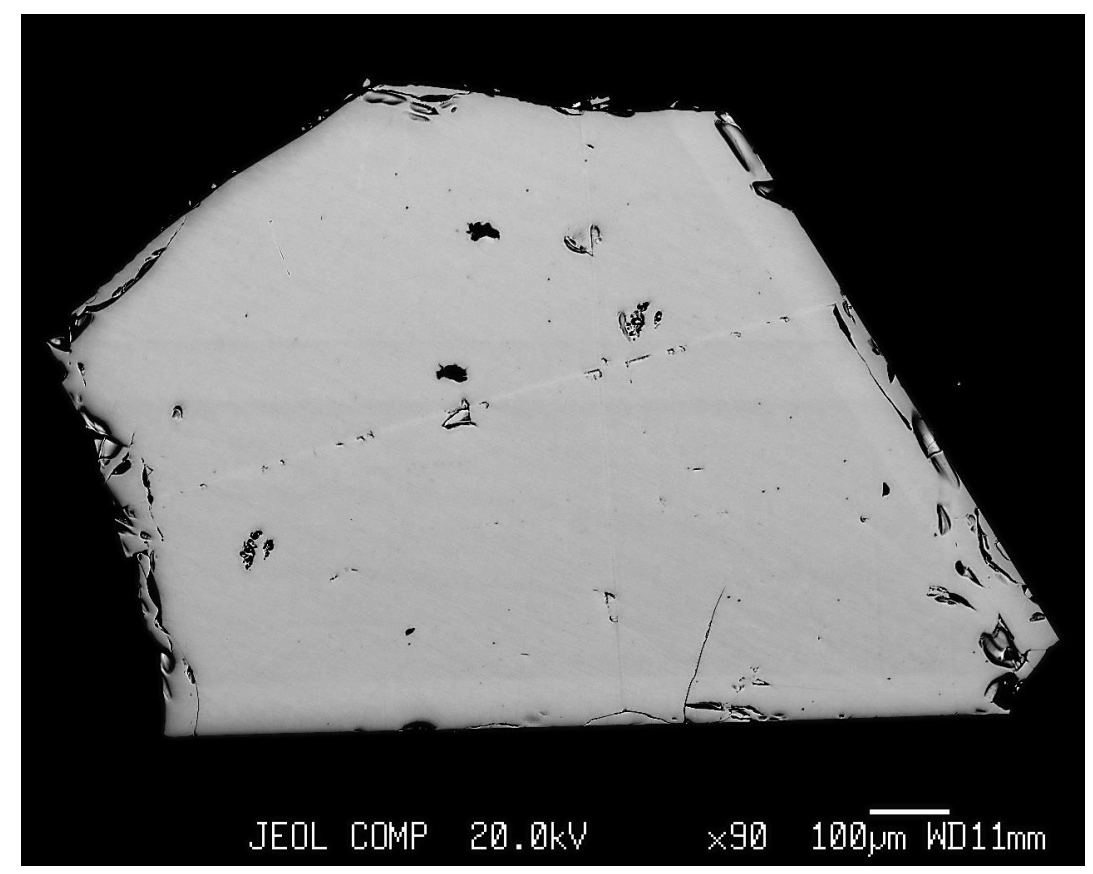

Figure 3. The scanning image in back scattered electrons (BSEs) of magnetite crystal (Experiment 8, Table 1). Note the homogeneity in elements' distribution inside of a crystal. 


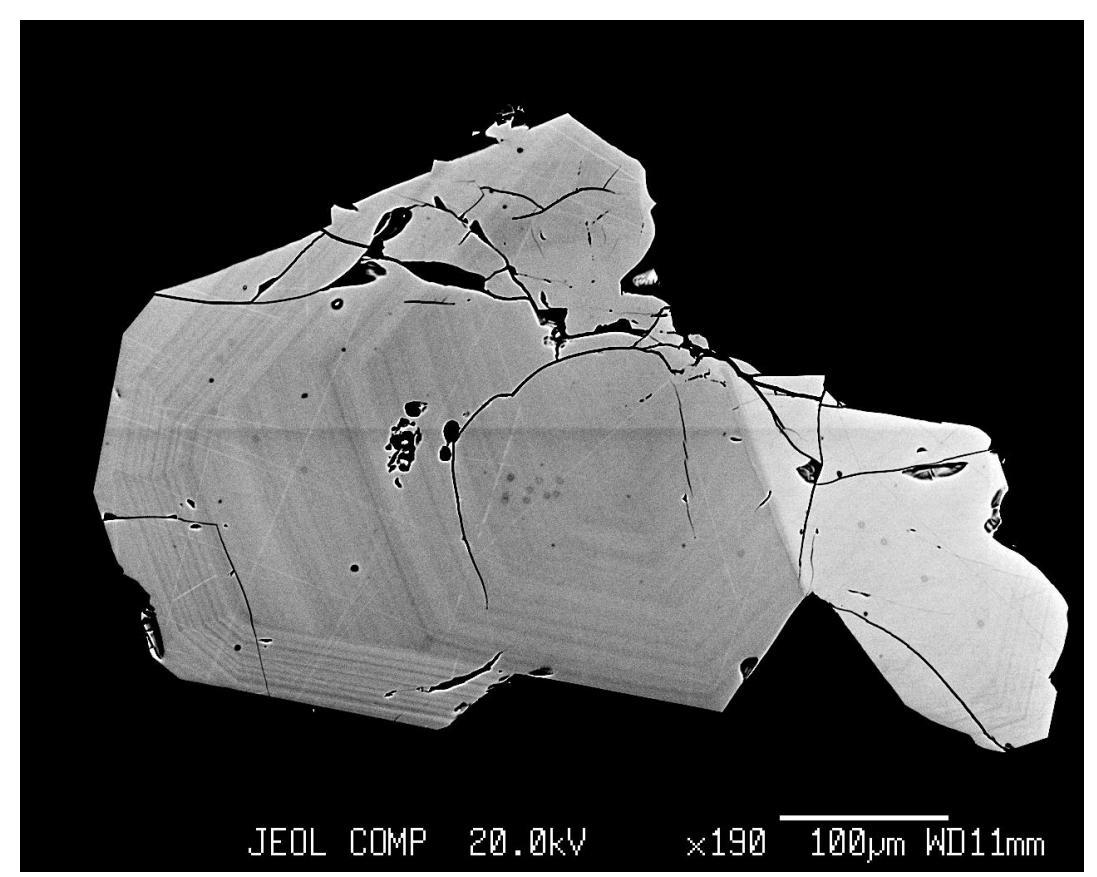

Figure 4. BSE image of hematite and magnetite crystals intergrowth from Experiment 11 (Table 1). Fine growth zoning in hematite crystal is clearly seen.

\subsection{Partition and Co-Crystallisation Coefficients}

Table A1 in Appendix A presents the results of EPMA, LA-ICP-MS, and AAS of crystals obtained in the hydrothermal experiments (see Table 1 for conditions, phases synthesised, and Fe content in trapped fluids). The atomic ratios of TE/Fe in minerals and fluids and the partition and co-crystallisation coefficients calculated for the most reliable data with a minimum standard deviation of the mean (Table A1). Only limited data sets were obtained for hematite and Ni-spinel; thus, these results are considered preliminary and require further experimental validation to substantiate initial findings.

For a majority of elements, we noticed reasonable agreement among different analytical methods including the bulk AAS. Discrepancies between them did not exceed $\pm 30 \%$; however, some elements demonstrated a lack of correlation between the AAS data and the data obtained by other methods. This was dramatically evident for $\mathrm{Cu}$; based on AAS results, the $\mathrm{Cu}$ content in magnetite and hematite crystals ranged from 32 to $3500 \mu \mathrm{g} / \mathrm{g}$, whereas results from EPMA were below the MDL, and LA-ICP-MS only detected 2.7-17.1 $\mu \mathrm{g} / \mathrm{g} \mathrm{Cu}$ (Table A1). The elevated contents in comparison to LA-ICP-MS were also observed for $\mathrm{Zn}$ and $\mathrm{Cr}$ in hematite as determined by AAS. One possible reason for the effect of the lack of correlation between methods is the enrichment of TEs on crystal surfaces (see Sections 4.3 and 5.3). The partition and co-crystallisation coefficients are shown in Table 2.

Data obtained in this work were supplemented with results for Mn [26] and $\mathrm{Cr}$ and $\mathrm{V}$ [27] partitioning in magnetite-fluid systems previously obtained under the same temperature and pressure parameters as before and a similar composition of mineralising solution. The co-crystallisation coefficients are presented in Table 2 and in Figure 5. 
Table 2. Average partition and co-crystallisation coefficients of trace elements (TE) in magnetite (Mt), $\mathrm{Ni}$-spinel (Ni-Sp) and hematite $(\mathrm{Hm})$ in the system mineral-hydrothermal fluid at $450{ }^{\circ} \mathrm{C}$ and $1 \mathrm{kbar}$.

\begin{tabular}{|c|c|c|c|}
\hline Element & Mineral Phase & $D_{p} \pm \varepsilon *$ & $D_{\mathrm{TE} / \mathrm{Fe}} \pm \varepsilon *$ \\
\hline \multirow{3}{*}{$\mathrm{Ti}$} & Mt & $1.6 \pm 1.8$ & $(1.4 \pm 0.9) \times 10^{-2}$ \\
\hline & $\mathrm{Ni}-\mathrm{Sp}$ & 0.1 & $1.2 \times 10^{-3}$ \\
\hline & $\mathrm{Hm}$ & $31 \pm 28$ & $0.4 \pm 0.3$ \\
\hline \multirow{3}{*}{ Co } & Mt & $19 \pm 17$ & $0.16 \pm 0.07$ \\
\hline & $\mathrm{Ni}-\mathrm{Sp}$ & 3 & 0.05 \\
\hline & $\mathrm{Hm}$ & $0.2 \pm 0.1$ & $(1.2 \pm 0.6) \times 10^{-3}$ \\
\hline \multirow{3}{*}{$\mathrm{Ni}$} & Mt & $330 \pm 250$ & $3.0 \pm 1.5$ \\
\hline & $\mathrm{Ni}-\mathrm{Sp}$ & 220 & 4.0 \\
\hline & $\mathrm{Hm}$ & 7.7 & $(4 \pm 3) \times 10^{-2}$ \\
\hline \multirow{3}{*}{$\mathrm{Cu}$} & Mt & $(9.1 \pm 2.3) \times 10^{-4}$ & $(1.9 \pm 1.6) \times 10^{-5}$ \\
\hline & $\mathrm{Ni}-\mathrm{Sp}$ & $4.5 \times 10^{-4}$ & $5.8 \times 10^{-6}$ \\
\hline & $\mathrm{Hm}$ & 0.01 & $7.1 \times 10^{-5}$ \\
\hline \multirow{3}{*}{$\mathrm{Zn}$} & Mt & $0.13 \pm 0.04$ & $(1.7 \pm 0.8) \times 10^{-3}$ \\
\hline & $\mathrm{Ni}-\mathrm{Sp}$ & 0.06 & $8 \times 10^{-4}$ \\
\hline & $\mathrm{Hm}$ & $5 \times 10^{-4}$ & $(1.0 \pm 0.7) \times 10^{-5}$ \\
\hline \multirow{3}{*}{$\mathrm{Al}$} & $\mathrm{Mt}$ & $260 \pm 210$ & $5.3 \pm 4$ \\
\hline & $\mathrm{Ni}-\mathrm{Sp}$ & 37 & 0.3 \\
\hline & $\mathrm{Hm}$ & $610 \pm 190$ & $7.5 \pm 7$ \\
\hline \multirow{2}{*}{ Mn } & $\mathrm{Mt} * *$ & $0.3 \pm 0.1$ & $(9 \pm 2) \times 10^{-3}$ \\
\hline & $\mathrm{Hm}$ & $4.8 \times 10^{-3}$ & $(2.0 \pm 0.3) \times 10^{-5}$ \\
\hline \multirow{2}{*}{$\mathrm{Cr}$} & $\mathrm{Mt} * *$ & 140 & $1.2 \pm 1$ \\
\hline & $\mathrm{Hm}$ & $9.8 \pm 8$ & $(7.5 \pm 6) \times 10^{-2}$ \\
\hline \multirow{2}{*}{ V } & $\mathrm{Mt} * *$ & 540 & $6.6 \pm 3.8$ \\
\hline & $\mathrm{Hm}$ & 1200 & $6.1 \pm 5.9$ \\
\hline
\end{tabular}

* Errors were calculated as $\varepsilon=t_{\alpha n} \times S_{x} / \sqrt{n}$ at a confidence level of 0.9 for more than 3 experiments $(\mathrm{n}>3)$ and at a confidence level of 0.8 for $n=3$. For $n=2$ and highly discrepant values at $n=3$ (Table A1), the mean is given. $t_{\alpha n}$ is the Student's coefficient, $S_{x}$ is the root-mean-square deviation. ${ }^{* *}$ Data for magnetite obtained under similar conditions were taken from [26] (Mn) and [27] (Cr, V).

The elements under investigation were divided into four groups shown in different colours (Figure 5). The highest values for $D_{T E / F e}^{\mathrm{min} / f l} \approx(0 . n-n)$ characterised Ti in hematite, $\mathrm{V}$ in magnetite and hematite, $\mathrm{Cr}$ in magnetite, $\mathrm{Ni}$ in magnetite and $\mathrm{Ni}$-spinel, and $\mathrm{Al}$ in all three phases. The second group with $D_{T E / F e}^{\mathrm{min} / f l} \approx(0.0 n-0 . n)$ included Ti, Mn, and Co in magnetite, $\mathrm{Cr}$ and $\mathrm{Ni}$ in hematite, and $\mathrm{Co}$ in Ni-spinel.

The third group comprised Ti and Zn in Ni-spinel, Co in hematite, and Zn in magnetite with co-crystallisation coefficients at the level of $\sim 10^{-3}$. The lowest values of $D_{T E / F e}^{\mathrm{min} / f l}$ $\left(\mathrm{n} \times 10^{-5}\right)$ are distinctive features of $\mathrm{Mn}$ and $\mathrm{Zn}$ in hematite and $\mathrm{Cu}$ in all three phases (Table 2). Variations in co-crystallisation and partition coefficients were sufficiently large, especially for Ni-spinel and hematite, for which only two and three experiments were available, respectively. The data for magnetite were more representative. In most cases, the coefficient of variation is lower for $D_{T E / F e}^{\mathrm{min} / f l}$ than for the partition coefficient $D_{p}^{\mathrm{min} / f l}$ (Table 3), demonstrating better reproducibility in the co-crystallisation coefficient compared to the partition coefficient. These data may be explained relying on Equation (2) (Section 2): $F_{\mathrm{TE}} / F_{\mathrm{Fe}}$ can be tolerant to the changes of physicochemical conditions due to chemical similarity of the elements (TE and $\mathrm{Fe}$ ), whereas $F_{\mathrm{TE}}$ by itself can vary in more wide range changing the $D_{p}^{\mathrm{min} / f l}$ value. 


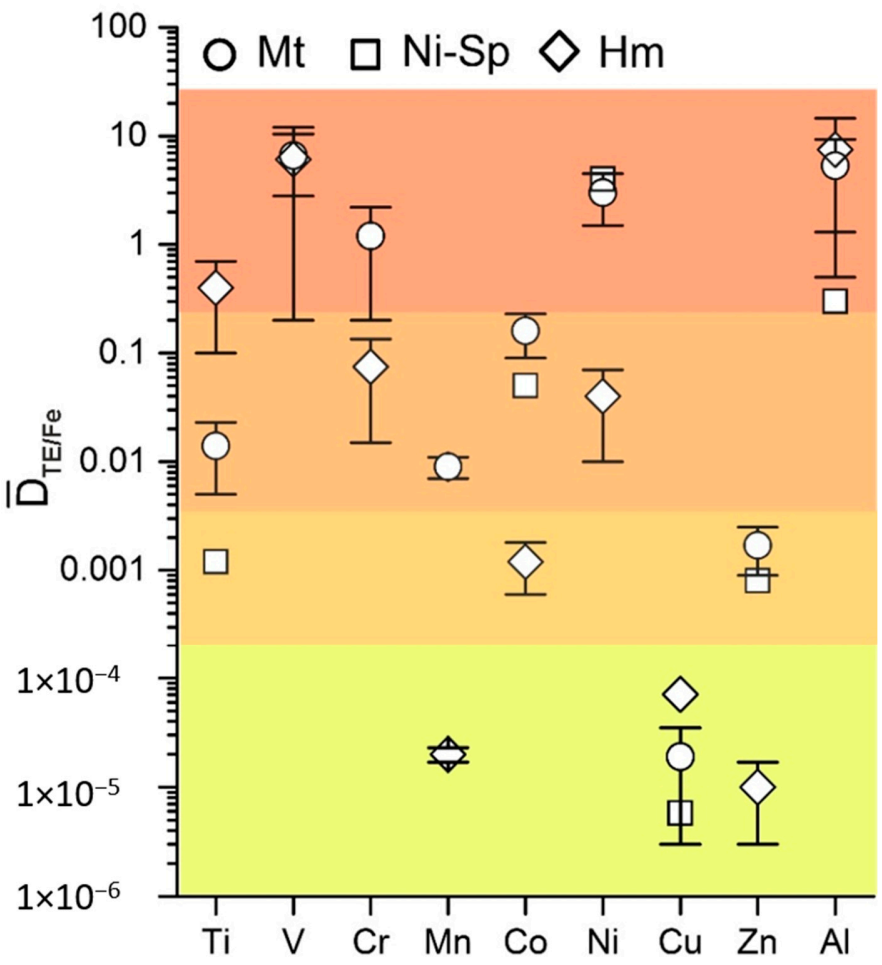

Figure 5. Average co-crystallisation coefficients of trace elements in magnetite, Ni-spinel and hematite at $450{ }^{\circ} \mathrm{C}, 1$ kbar. The same colour marks similar $\mathrm{D}_{\mathrm{TE} / \mathrm{Fe}}$ values.

Table 3. Reproducibility of partition and co-crystallisation coefficients of TE in magnetite according to the coefficient of variation.

\begin{tabular}{ccc}
\hline Element & $\mathbf{v}\left(\boldsymbol{D}_{\boldsymbol{p}}\right), \%$ & $\mathbf{v}\left(\boldsymbol{D}_{\mathrm{TE} / \mathrm{Fe}}\right), \%$ \\
\hline $\mathrm{Ti}$ & 160 & 100 \\
$\mathrm{Co}$ & 130 & 60 \\
$\mathrm{Ni}$ & 100 & 70 \\
$\mathrm{Cu}$ & 40 & 110 \\
$\mathrm{Zn}$ & 40 & 70 \\
$\mathrm{Al}$ & 110 & 100 \\
$\mathrm{Mn}{ }^{*}$ & 40 & 20 \\
$\mathrm{Cr}^{*}$ & 160 & 70 \\
$\mathrm{~V}^{*}$ & 130 & 50 \\
\hline
\end{tabular}

${ }^{*}$ Data from $[26,27]$.

\subsection{Surficial Crystal Enrichment with TE}

The result of layer-by-layer LA-ICP-MS analysis of magnetite crystals in six laser passes are shown in Figures 6 and 7. Crystals from Experiments 1 and 5 (Tables 1 and A1) with smooth faces and low mean surface roughness ( $20 \mathrm{~nm}$ from AFM data) were used. The first one or two passes showed markedly higher TE contents than those for volume (Figures 6 and 7). This was not as relevant for elements with relatively high contents (1-2\% of $\mathrm{Ni}$ and $\mathrm{Co}$ each) but was clearly essential for minor elements $(\leq 0.1 \%$ of TE). The highest concentrations of TEs were associated mostly with the first layer removed, for which the thickness was estimated at $1-1.5 \mu \mathrm{m}$ (see also $[17,33]$ ). The second lasers pass partly utilised material spattered and redeposited after the first pass. Therefore, the scale of the effect observed was comparable to the size parameters of the NAP on the surface of hydrothermal magnetite crystals ( 300 nm [30]). 

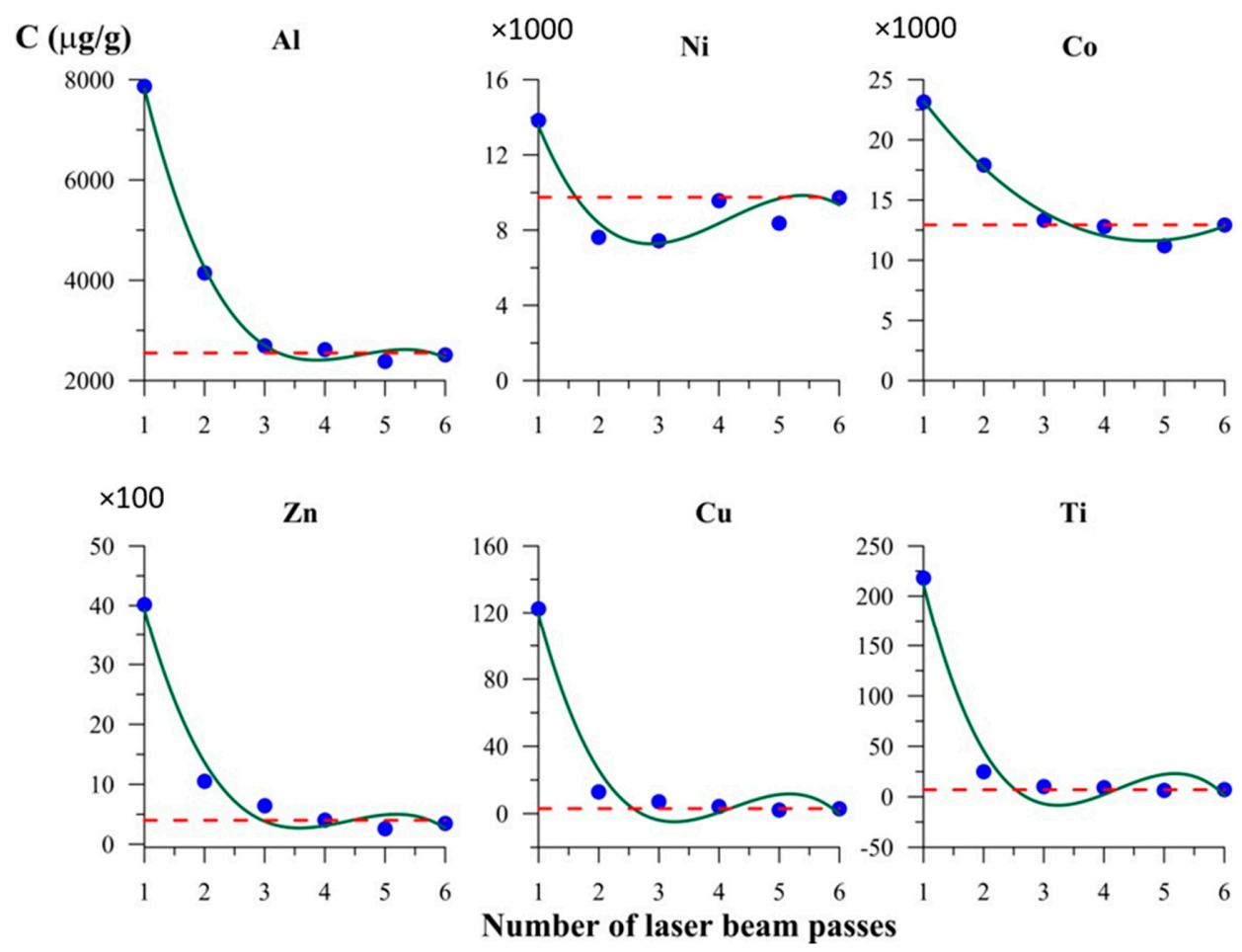

Figure 6. Elements content in the course of layer-by-layer laser ablation inductively coupled plasma mass spectrometry (LA-ICP-MS) analysis of crystal surface. Magnetite crystal from Experiment 1 (Tables 1 and A1). The first two laser passes distinctly detect higher contents of TE with respect to the volume concentration (dotted line), although the uncertainty is relatively high for TEs in two most surficial lines (at a level of $\pm 30 \%$ rel.).
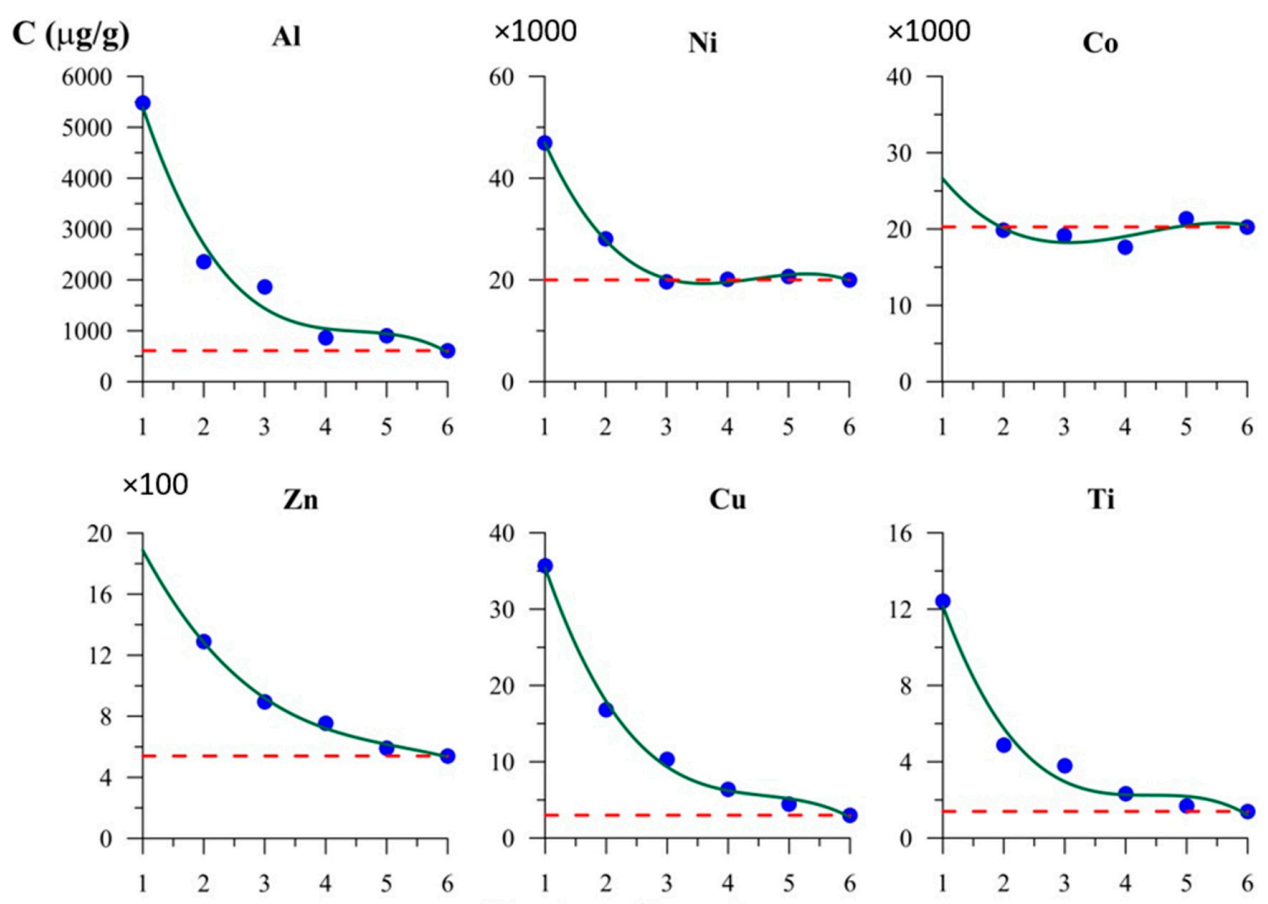

Number of laser beam passes

Figure 7. Elements content in the course of layer-by-layer LA-ICP-MS analysis of crystal surface. Magnetite crystal from Experiment 5 (Tables 1 and A1). 
Figures 8 and 9 show the fractal character of surficial objects distribution in the surficial layer of magnetite crystals. The heights of surficial objects relative to the surface area of minimal roughness rarely exceeded $100 \mathrm{~nm}$ (Figure 9).

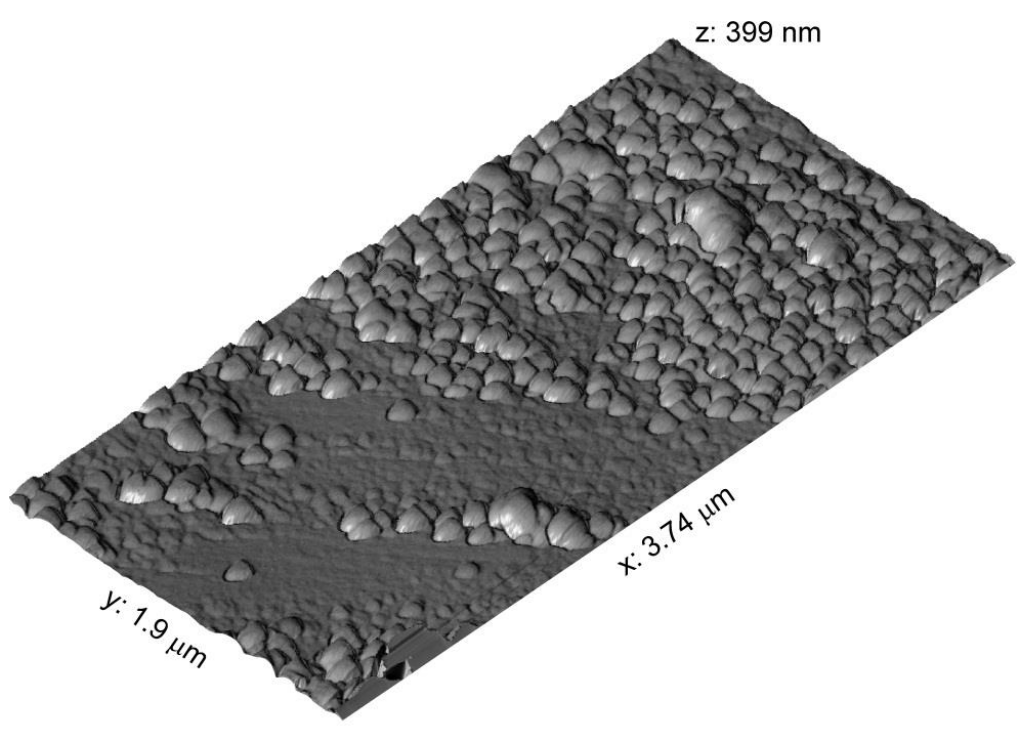

Figure 8. Atomic force microscopic image of magnetite crystal surface. The crystal from Experiment 1 (Table 1). Relatively uniform nonautonomous phase (NAP) coverage and two populations of the surficial submicron-sized objects.
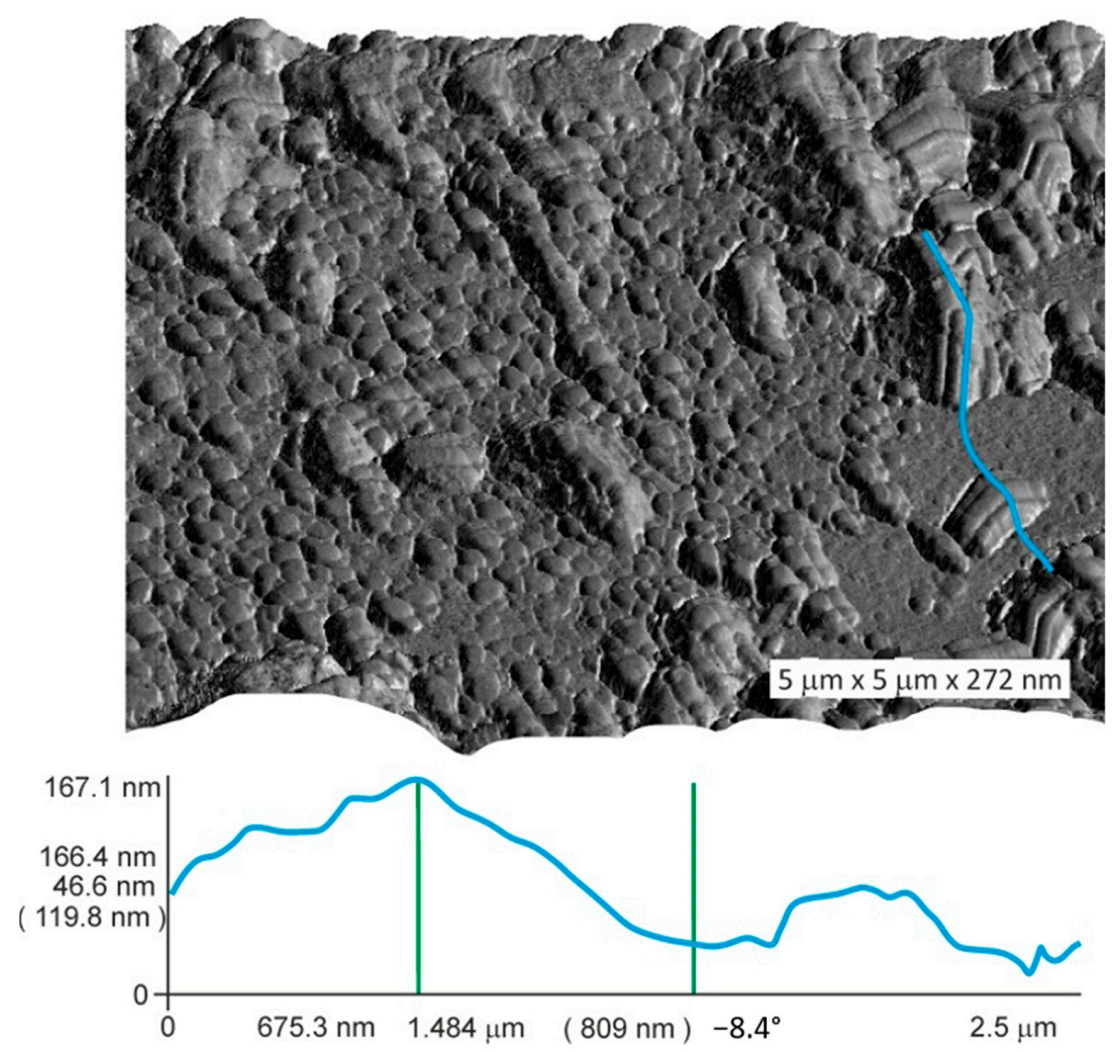

Figure 9. Atomic force microscopic image of magnetite crystal surface. The crystal from Experiment 5 (Table 1). Surface relief along the blue line shows the level difference of $\sim 120 \mathrm{~nm}$. 


\section{Discussion}

\subsection{Comparison with Previous Experimental Data}

Ilton and Eugster [16] studied $\mathrm{Mn}, \mathrm{Zn}, \mathrm{Cu}$, and Cd co-crystallisation in magnetite at $600-800{ }^{\circ} \mathrm{C}$ and $2 \mathrm{kbar}$ pressure. Although only two experimental points were available for $\mathrm{Cu}$, the result at $650^{\circ} \mathrm{C}\left(D_{\mathrm{Cu} / \mathrm{Fe}}^{\mathrm{Mt} / \mathrm{qq}}=1.3 \times 10^{-5}\right)$ was surprisingly close to that obtained in this study at $450^{\circ} \mathrm{C}\left(D_{\mathrm{Cu} / \mathrm{Fe}}^{\mathrm{Mt} / \mathrm{q}}=1.9 \times 10^{-5}\right.$, Table 2$)$. Ilton and Eugster obtained the temperature dependences for $\mathrm{Mn}$ and $\mathrm{Zn}$, which gave $D_{\mathrm{Mn} / \mathrm{Fe}}^{\mathrm{Mt} / \mathrm{qq}}=3.7 \times 10^{-3}$ and $D_{\mathrm{Zn} / \mathrm{Fe}}^{\mathrm{Mt} / \mathrm{qq}}=1.8 \times 10^{-3}$ when extrapolated to $450^{\circ} \mathrm{C}$ using expressions given in [16]. The co-crystallisation coefficient for $\mathrm{Zn}$ conforms ideally to the one obtained here, that is, $(1.7 \pm 0.8) \times 10^{-3}$ (Table 2); whereas a small offset was observed for Mn $\left(7.6 \times 10^{-3}\right.$ in this work (Table A1) and $(9 \pm 2) \times 10^{-3}$ in [26]). The mismatch becomes smaller if non-ideality in Mn-Fe mixing and occupation of octahedral B positions by $\mathrm{Mn}^{2+}$ in the magnetite structure is taken into account $\left(D_{M n / F e}^{450 C}=0.011\right)$.

$D_{\mathrm{Cu} / \mathrm{Fe}}^{\mathrm{Mt} / \mathrm{aq}}$ is very small and may be weakly dependent on temperature, whereas $\mathrm{Mn}$ and $\mathrm{Zn}$ obey Henry's law and exhibit linear dependence of $\ln 1 / D_{T E / F e}^{M t / a q}$ on the reciprocal absolute temperature, at least in the interval $800-450{ }^{\circ} \mathrm{C}$. An important inference was made when studying $\mathrm{Mn}$ partitioning in a multiphase magnetite-pyrrhotite-pyrite hydrothermal system at $450^{\circ} \mathrm{C}$ and $1 \mathrm{kbar}$ [26]. The value obtained $\left(D_{M n / F e}^{M t / a q}=9.5 \times 10^{-3}\right)$ demonstrated the independence of this parameter on the presence of sulphide phases coexisting with magnetite. Although in general case the co-crystallisation coefficient is dependent on the composition of multi-component system, in some special cases the effect of the system complexity is negligible. This occurs when $D$ does not change significantly due to the chemical similarity of the elements co-crystallised, unmixing of coexisting solid phases (saturation in different kind of anions like sulphide and oxide) and validity of the model of complex solvent $[21,24,25]$. The most reliable data may be obtained from the study of "pair" co-crystallisation coefficients of chemically similar elements such as $D_{\mathrm{Ni} / \mathrm{C} o}, D_{V / C}$, $D_{M n / Z n}, D_{M g / Z n}$, etc. In addition, we partially confirmed the conclusion of [27] that the co-crystallisation coefficient is less variable than the partition coefficient $D_{p}$ (Table 3), and therefore, is preferred for the analysis of element partitioning in fluid-mineral systems. However, $\mathrm{Cu}$ and $\mathrm{Zn}$ present an exception to this rule (Table 3). Moreover, data eliminate doubts about the application of distribution coefficients in the presence of components such as $\mathrm{Ti}, \mathrm{Al}$, and $\mathrm{Cr}$ [16] because in our experiments all elements were introduced into the system simultaneously.

In the present work, we dealt with partitioning of the majority of main discriminator elements for magnetite, which included $\mathrm{Mg}$, $\mathrm{Al}, \mathrm{Ti}, \mathrm{V}, \mathrm{Cr}, \mathrm{Mn}, \mathrm{Co}, \mathrm{Ni}, \mathrm{Zn}$, and $\mathrm{Ga}$, according to [14]. TE partitioning in magnetite in hydrothermal systems differs significantly from igneous magnetite. Among the elements studied in this work, only Al was clearly incompatible $\left(D_{p} \sim 0.1\right)$, whereas other elements (except $\mathrm{Cu}$ for which no data were presented) were compatible in magnetite and had $D_{p}$ values from $\sim 1$ to 100 [14]. In contrast, our results revealed the compatibility of $\mathrm{Al}$ and the incompatibility of $\mathrm{Zn}$ and $\mathrm{Mn}$ in magnetite in a hydrothermal system (Table 2). The behaviour of $\mathrm{Co}, \mathrm{Ni}, \mathrm{Cr}$, and $\mathrm{V}$ in the hydrothermal system did not contradict distribution constants in the magnetite-silicate melt systems.

\subsection{TE Partitioning in Magnetite and Hematite: Implications for Natural Fluid Composition}

Despite the lower reliability of data obtained for hematite as compared to magnetite (Tables 2 and A1), it is essential to define differences between them with respect to partitioning of common TEs and compositions of the fluids coexisting in equilibrium with both minerals. If crystallised from one and the same hydrothermal solution, magnetite and hematite might have similar contents of elements such as $\mathrm{Al}, \mathrm{Cu}$, and $\mathrm{V}$, whereas hematite might be enriched in $\mathrm{Ti}$ and depleted in $\mathrm{Co}, \mathrm{Ni}, \mathrm{Zn}, \mathrm{Mn}$, and $\mathrm{Cr}$ as compared to magnetite (Table 2). Therefore, it seems to be not necessarily that if magnetite and hematite from the same ores have similar trace element contents, then they were derived from 
the same ore fluids [12]. TE/Fe ratios in the fluid phase were calculated using the data presented in [12] and in Table 2 of the present work. The fluid coexisting with magnetite was enriched in Ti 25-30 times, and highly depleted in $\mathrm{Cr}, \mathrm{Mn}, \mathrm{Co}, \mathrm{Ni}$, and $\mathrm{Zn}$ (1-3 orders of magnitude), relative to fluid coexisting with hematite. This fact is impossible to explain under the assumption of one and the same fluid with a certain Fe content. Therefore, it is hardly possible that magnetite and hematite having similar TE compositions were formed simultaneously in equilibrium with the same fluid phase. The data presented in [12] show that fluids equilibrated with magnetite and hematite differed in composition with respect to the majority of TEs (except possibly $\mathrm{Al}$ and $\mathrm{V}$ ).

An analysis of the composition of fluids involved in the formation of the Yuleken porphyry Cu-Mo deposit in northwestern China [15] was performed because temperatures during the hydrothermal stages of ore formation $\left(450-400{ }^{\circ} \mathrm{C}\right)$ is close to the temperature used in the present study. Average TE/Fe ratios calculated for fluids at three stages of hydrothermal activity are presented in Table 4.

Table 4. Proportions $(\mathrm{TE} / \mathrm{Fe})^{\mathrm{fl}}$ calculated on the basis of obtained $D_{T E / F e}^{M t / f l}$ and the data of LA-ICP-MS for magnetites formed at hydrothermal stages $\left(450-400^{\circ} \mathrm{C}\right)$ of the formation of the Yuleken porphyry Cu-Mo deposit (NW China) [15]

\begin{tabular}{|c|c|c|c|c|c|c|c|c|c|c|}
\hline \multirow{2}{*}{$\begin{array}{c}\text { Sample } \\
\text { No. }\end{array}$} & \multirow{2}{*}{ Stage } & \multicolumn{9}{|c|}{$(\mathrm{TE} / \mathrm{Fe})^{\mathrm{fl}}$} \\
\hline & & Al & $\mathrm{Ti}$ & Mn & $\mathrm{V}$ & $\mathrm{Cr}$ & Co & $\mathrm{Ni}$ & $\mathrm{Cu}$ & $\mathrm{Zn}$ \\
\hline $\operatorname{Mag}_{\mathrm{II}}$ & $\begin{array}{c}\mathrm{Na}-\mathrm{Ca} \\
\text { alteration }\end{array}$ & $4.9 \times 10^{-4}$ & 0.056 & 0.11 & $3.8 \times 10^{-4}$ & $2.5 \times 10^{-5}$ & $2.7 \times 10^{-4}$ & $3.3 \times 10^{-6}$ & 0.08 & 0.16 \\
\hline Mag $_{\text {III-A }}$ & $\begin{array}{c}\text { Early potassic } \\
\text { with no } \\
\text { sulphides }\end{array}$ & $5.2 \times 10^{-4}$ & 0.056 & 0.12 & $3.9 \times 10^{-4}$ & $9.3 \times 10^{-6}$ & $2.1 \times 10^{-4}$ & $1.1 \times 10^{-6}$ & 0.08 & 0.09 \\
\hline Mag $_{\text {III-B }}$ & $\begin{array}{l}\text { Late potassic } \\
\text { with } \\
\text { sulphides }\end{array}$ & $5.4 \times 10^{-4}$ & 0.032 & 0.14 & $3.9 \times 10^{-4}$ & $1.2 \times 10^{-5}$ & $7.5 \times 10^{-6}$ & $2.4 \times 10^{-6}$ & 0.34 & 0.12 \\
\hline
\end{tabular}

Changes in fluid composition appeared to accompany the transition from early to late potassic stage as distinguished by the appearance of sulphides. Ti/Fe and $\mathrm{Co} / \mathrm{Fe}$ ratios decreased while $\mathrm{Cu} / \mathrm{Fe}$ increased appreciably. It is interesting to note that $\mathrm{Mn}, \mathrm{Cu}$, and $\mathrm{Zn}$ were the most abundant metals in fluids after Fe; they contributed $~ 10$ to $30 \%$ of the iron content. The second most abundant TE was Ti contributing about $5 \%$ of the Fe content, followed by V and $\mathrm{Al}$ at (4-5) $\times 10^{-2 \%}$, and then $\mathrm{Co}\left(2 \times 10^{-2 \%}\right), \mathrm{Cr}\left(2 \times 10^{-3} \%\right)$, and $\mathrm{Ni}\left(2 \times 10^{-4 \%}\right)$. However, this study does not intend to be exhaustive in application to different porphyry deposits where the magnetite stability and composition depends on several factors: changes in intensive parameters, late fluid overprinting, etc. Calculations performed for other deposits of magmatic-hydrothermal genesis [12,13] fully support the prevalence of $\mathrm{Mn}$ and $\mathrm{Zn}$ ( $\mathrm{Cu}$ was rarely detected) and the intermediate position of $\mathrm{Ti}$, whereas other TEs can vary in the interval $\left(n \times 10^{-1}-n \times 10^{-4} \%\right)$ of the Fe content. The information that skarn fluids in equilibrium with magnetite containing minor Mn can have $\mathrm{Mn} / \mathrm{Fe}$ ratios greater than one [16] should be supplemented with $\mathrm{Zn} / \mathrm{Fe}$ ratios because $\mathrm{Zn}$ has a co-crystallisation coefficient $D_{T E / F e}^{M t / a q}$ even lower than Mn (Table 2).

\subsection{Surficial Effect on TE Accumulation}

The surficial effect is important and must be considered, especially in the study of dispersed mineral systems in both experimental and natural environments (sedimentary, diagenetic, seafloor Mn-Fe nodules, crusts, and so on). The XPS data revealed two valence states for iron $\left(\mathrm{Fe}^{3+}\right.$ and $\left.\mathrm{Fe}^{2+}\right)$ as in the magnetite volume structure but in different proportions (1:1 instead of 2:1, respectively), and the presence of hydroxyl ions and cation vacancies support the hypothesis of the formation of surficial NAP of oxyhydroxide composition $[17,33]$. The incorporation of metal cations like $\mathrm{Cr}$ and $\mathrm{Ni}$ increased the amount of surface hydroxyls due to stronger Lewis acid activity of cations substituting iron [34]. 
The functional hydroxyl groups enhanced metal adsorption in the surficial crystal layer. The increased accumulation potential of NAP was due to the presence of hydroxyl ions, unsaturated chemical bonds, and structural disorder (including metal and oxygen vacancies), that weakened the crystal-chemical control of element incorporation [29]. For instance, there appeared to be an opportunity to realise the surficial goethite-like phases of oxyhydroxide composition and structural incorporation of elements from the iron group plus aluminium [35].

In this work, we rarely encountered discrepancies between data collected with bulk and local methods because we used relatively large crystals with low specific surface area. However, the example for $\mathrm{Cu}$ showed that for crystals as large as 1-2 mm, the surficial accumulation may increase the measured $\mathrm{Cu}$ bulk content up to 1-2 orders of magnitude (Table A1). Copper contents in the volume of crystals were determined as $\sim 3-17 \mu \mathrm{g} / \mathrm{g}$. The same level of TE concentrations was observed for $\mathrm{Zn}$ and $\mathrm{Cr}$ in hematite, and these cases also demonstrate the excess of bulk content compared to local one up to an order of magnitude and more. Figures 6 and 7 leave no doubt that $\mathrm{Cu}$ and Ti are highly subjected to the TE accumulation effect due to NAP presence that might be the reason for inconsistency of the data on $\mathrm{Cu}$ distribution in hydrothermal magnetite (see Section 1).

The TE surface segregation provides a significant contribution to the average concentration of microelements even with a low thickness of the surficial NAP enriched with it, as the AFM study showed. The crystal surface contains nano-objects of different sizes with smaller surficial objects that repeat the morphological features of coarser objects (Figures 8 and 9). The fractality is important for the absorption of TEs by NAP because it points to an increase in the real surface as compared to the topological surface. The data obtained show that one needs to be very careful with the results acquired through bulk analyses, with the crystals small enough and the lack of size control [36].

\section{Conclusions}

We present the first data on partitioning of several discriminator elements for magnetite in mineral-hydrothermal fluid systems at $450{ }^{\circ} \mathrm{C}$ and $1 \mathrm{kbar}$. The three mineral phases studied were magnetite, $\mathrm{Ni}$-spinel, and hematite, the last two supported by a limited data set. The element series $\mathrm{Ni}, \mathrm{Co}, \mathrm{Al}, \mathrm{Cr}$, and $\mathrm{V}$ and $\mathrm{Ti}, \mathrm{Ni}, \mathrm{Al}, \mathrm{Cr}$, and $\mathrm{V}$ are shown to be compatible in magnetite and hematite, respectively. On the other hand, $\mathrm{Zn}, \mathrm{Mn}$, and $\mathrm{Cu}$ are incompatible in magnetite, and $\mathrm{Co}, \mathrm{Zn}, \mathrm{Mn}$, and $\mathrm{Cu}$ are incompatible in hematite. The highest values for the co-crystallisation coefficient $D_{\mathrm{TE} / \mathrm{Fe}}(0 . n-n)$ characterised Ti in hematite, $\mathrm{V}$ in magnetite and hematite, $\mathrm{Cr}$ in magnetite, $\mathrm{Ni}$ in magnetite and $\mathrm{Ni}$-spinel, and $\mathrm{Al}$ in all three phases. The second group with $D_{\mathrm{TE} / \mathrm{Fe}} \approx 0.0 n-0 . n$ includes $\mathrm{Ti}, \mathrm{Mn}$, and Co in magnetite, $\mathrm{Cr}$ and $\mathrm{Ni}$ in hematite, and $\mathrm{Co}$ in Ni-spinel. The third group is represented by $\mathrm{Ti}$ and $\mathrm{Zn}$ in Ni-spinel, $\mathrm{Co}$ in hematite, and $\mathrm{Zn}$ in magnetite characterised by co-crystallisation coefficients on the order of $10^{-3}$. The lowest values $\left(n \times 10^{-5}\right)$ are distinctive features of $\mathrm{Mn}$ and $\mathrm{Zn}$ in hematite and $\mathrm{Cu}$ in all three phases. According to the co-crystallisation coefficients, magnetite and hematite crystallised from the same hydrothermal solution may display similar contents of $\mathrm{Al}, \mathrm{Cu}$, and $\mathrm{V}$, whereas hematite must be enriched in $\mathrm{Ti}$ and depleted in $\mathrm{Co}, \mathrm{Ni}, \mathrm{Zn}, \mathrm{Mn}$, and $\mathrm{Cr}$ as compared to magnetite. Magnetite oxidation and its transformation into hematite under hydrothermal conditions will cause the release of $\mathrm{Co}, \mathrm{Ni}, \mathrm{Zn}, \mathrm{Mn}$, and $\mathrm{Cr}$, and will not affect the behaviour of $\mathrm{Cu}, \mathrm{Al}$, and $\mathrm{V}$ and facilitate $\mathrm{Ti}$ absorption by the solid phase.

A fair amount of data on the composition of magnetite and hematite of various origins have been published; nevertheless, these data were of little relevance due to difficulties in adapting the data to reconstruct the composition of the ore-forming fluids. Using the partitioning data obtained in this study, the proportion of elements in the fluid involved in the formation of magnetite-containing deposits was evaluated. For the porphyry $\mathrm{Cu}-\mathrm{Mo}$ deposit, Fe was most abundant metal component in fluids, followed by $\mathrm{Mn}, \mathrm{Cu}$, and Zn which comprised $\sim 10$ to $30 \%$ of iron content. The less abundant TE was Ti which comprised $\sim 5 \%$ of Fe content, followed by $\mathrm{V}$ and $\left.\mathrm{Al}(4-5) \times 10^{-2} \%\right)$ and $\mathrm{Co}\left(2 \times 10^{-2} \%\right)$, 
$\mathrm{Cr}\left(2 \times 10^{-3 \%}\right)$, and Ni $\left(2 \times 10^{-4 \%}\right)$. The calculations performed to determine the fluid composition of magmatic-hydrothermal systems support the prevalence of $\mathrm{Mn}$ and $\mathrm{Zn}$ (and probably $\mathrm{Cu}$ ) and the intermediate ratios of Ti, whereas other TEs can vary in the interval of $0 . n$ to $n \times 10^{-4 \%}$ of Fe content.

The surficial segregation of TEs contributes to the average concentration of microelements even with thin surficial NAP layers enriched with TE ( 100 nm). At ppm and lower than ppm TE content, the surficial accumulation effect increased total TE content up to 1-2 orders of magnitude above concentrations inside of crystal even for coarse crystals.

Further development of this work involves the estimation of absolute TE concentrations over a wide range of temperature and salt composition of fluids. For this purpose, we plan to use magnetite solubility data [37] and physicochemical modelling [38]. Insights gained from this study can be applied to various hydrothermal systems using modern databases on thermodynamic properties of solid substances (magnetite and its solid solutions), hydrothermal solutions, and gas phases. This approach can help to solve the problem of using the magnetite composition as a quantitative indicator of TE concentrations in ore-forming fluids.

Author Contributions: N.S. coordinated the research experiments, provided analytical data processing, and contributed to the interpretation of results. V.T. formulated the problem, organised the research team, and guided the study. S.L. organised LA-ICP-MS analyses, obtained AFM images, managed data, and selected references on the problem. D.B. participated in the experimental program. T.P. performed 'wet' analytical work. O.B. performed EPMA data acquisition and interpretation. N.B. developed LA-ICP-MS analyses layer-by-layer. All authors have read and agreed to the published version of the manuscript.

Funding: The research was performed within the framework of state-ordered project IX.125.3.4, No. 0350-2019-0003 and was partially funded by the Russian Foundation for Basic Research, grant No. 18-05-00077.

Institutional Review Board Statement: Not applicable.

Informed Consent Statement: Not applicable.

Data Availability Statement: The data presented in this study are contained within the article and available in the references listed.

Acknowledgments: We thank Ekaterina Kaneva for X-ray measurements. Cooperation with the scientists at the Shared Research Center's 'Isotope-geochemical research' of the Vinogradov Institute of Geochemistry of SB RAS and 'Ultramicroanalysis' at the Limnological Institute of SB RAS are greatly appreciated. The authors would like to thank two anonymous reviewers for their deep insight into the problem, constructive criticism and useful comments.

Conflicts of Interest: The authors declare no conflict of interest. 


\section{Appendix A}

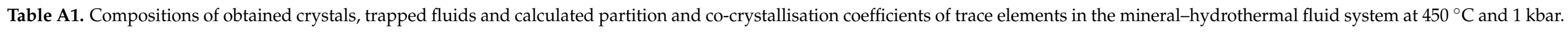

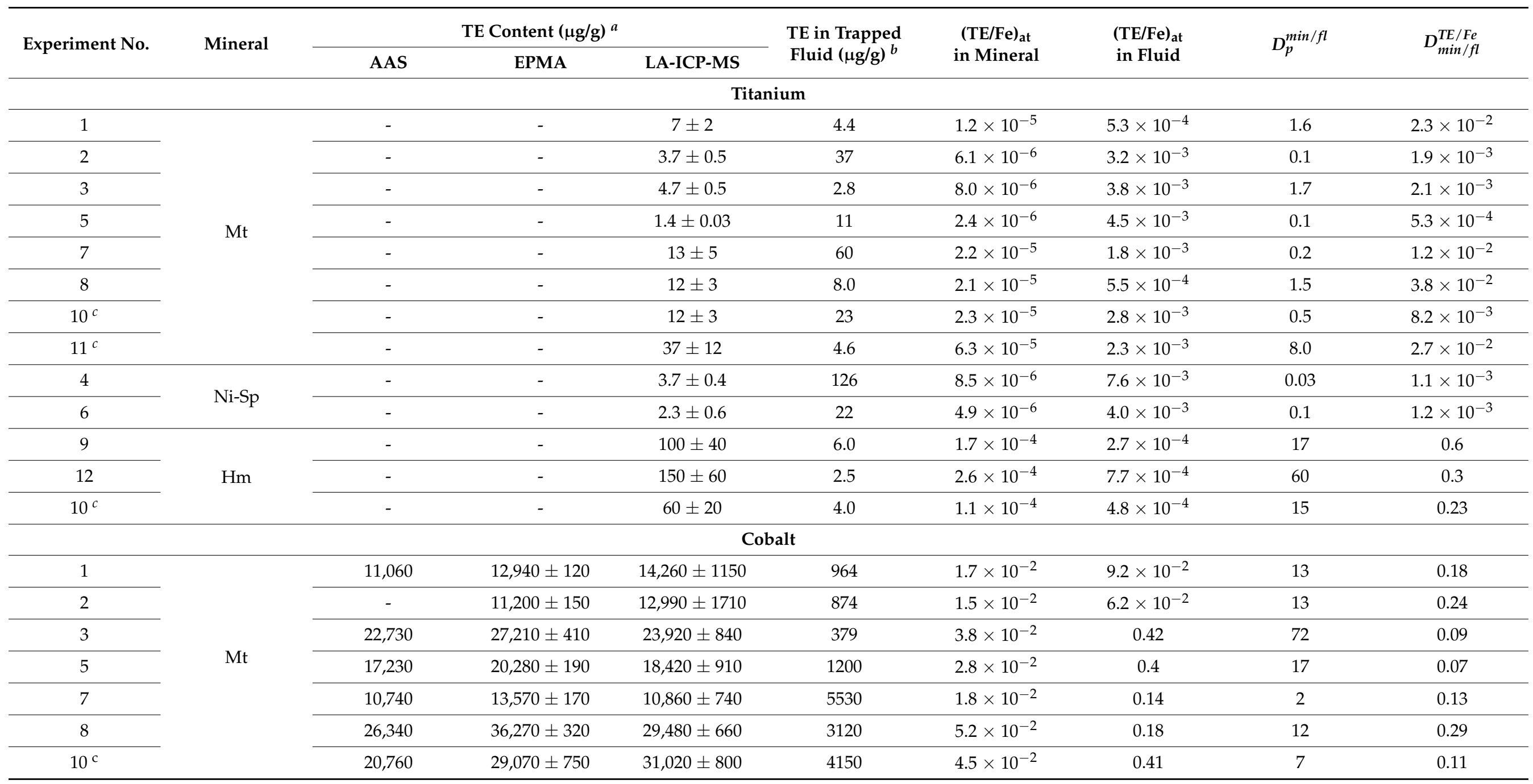


Table A1. Cont.

\begin{tabular}{|c|c|c|c|c|c|c|c|c|c|}
\hline \multirow{2}{*}{ Experiment No. } & \multirow{2}{*}{ Mineral } & \multicolumn{3}{|c|}{ TE Content $(\mu \mathrm{g} / \mathrm{g})^{a}$} & \multirow{2}{*}{$\begin{array}{l}\text { TE in Trapped } \\
\text { Fluid }(\mu \mathrm{g} / \mathrm{g})^{b}\end{array}$} & \multirow{2}{*}{$\begin{array}{c}(\mathrm{TE} / \mathrm{Fe})_{\mathrm{at}} \\
\text { in Mineral }\end{array}$} & \multirow{2}{*}{$\begin{array}{l}(\mathrm{TE} / \mathrm{Fe})_{\mathrm{at}} \\
\text { in Fluid }\end{array}$} & \multirow{2}{*}{$D_{p}^{\min / f l}$} & \multirow{2}{*}{$D_{\min / f l}^{T E / F e}$} \\
\hline & & AAS & EPMA & LA-ICP-MS & & & & & \\
\hline 4 & \multirow{2}{*}{$\mathrm{Ni}-\mathrm{Sp}$} & - & $7020 \pm 280$ & $7170 \pm 1200$ & 8220 & $1.3 \times 10^{-2}$ & 0.4 & 0.9 & 0.03 \\
\hline 6 & & - & $11,190 \pm 260$ & $10,900 \pm 1450$ & 2140 & $1.9 \times 10^{-2}$ & 0.32 & 5 & 0.06 \\
\hline 9 & \multirow[b]{2}{*}{$\mathrm{Hm}$} & 680 & - & $300 \pm 60$ & 6090 & $4.1 \times 10^{-4}$ & 0.22 & 0.05 & $1.9 \times 10^{-3}$ \\
\hline 12 & & 460 & - & $260 \pm 40$ & 1730 & $3.7 \times 10^{-4}$ & 0.43 & 0.2 & $8.6 \times 10^{-4}$ \\
\hline \multicolumn{10}{|c|}{ Nickel } \\
\hline 1 & \multirow{6}{*}{ Mt } & 11,480 & $9750 \pm 220$ & $11,900 \pm 1220$ & 41 & $1.3 \times 10^{-2}$ & $3.9 \times 10^{-3}$ & 238 & 3.3 \\
\hline 2 & & - & $16,390 \pm 930$ & $22,410 \pm 4420$ & 216 & $2.2 \times 10^{-2}$ & $1.5 \times 10^{-2}$ & 76 & 1.5 \\
\hline 3 & & 14,290 & $17,420 \pm 360$ & $13,310 \pm 1710$ & 17 & $2.4 \times 10^{-2}$ & $1.9 \times 10^{-2}$ & 1025 & 1.3 \\
\hline 5 & & 21,030 & $20,000 \pm 400$ & $17,300 \pm 2000$ & 45 & $2.8 \times 10^{-2}$ & $1.5 \times 10^{-2}$ & 444 & 1.9 \\
\hline 7 & & 14,190 & $15,430 \pm 700$ & $13,350 \pm 1350$ & 191 & $2.1 \times 10^{-2}$ & $4.8 \times 10^{-3}$ & 81 & 4.4 \\
\hline $10^{\mathrm{c}}$ & & 85,470 & $93,800 \pm 2240$ & $84,790 \pm 6300$ & 224 & 0.15 & $2.2 \times 10^{-2}$ & 419 & 6.8 \\
\hline 4 & \multirow{2}{*}{$\mathrm{Ni}-\mathrm{Sp}$} & - & $220,550 \pm 3850$ & - & 1880 & 0.41 & $9.3 \times 10^{-2}$ & 117 & 4.4 \\
\hline 6 & & - & $168,350 \pm 1060$ & - & 520 & 0.29 & $7.8 \times 10^{-2}$ & 324 & 3.7 \\
\hline 9 & \multirow{3}{*}{$\mathrm{Hm}$} & 3000 & $1410 \pm 130$ & $1330 \pm 340$ & 1300 & $1.9 \times 10^{-3}$ & $4.8 \times 10^{-2}$ & 1.1 & $4.0 \times 10^{-2}$ \\
\hline 12 & & 3560 & $1930 \pm 130$ & $2120 \pm 340$ & 922 & $2.8 \times 10^{-3}$ & 0.21 & 2.1 & $1.3 \times 10^{-2}$ \\
\hline $11^{c}$ & & - & $1980 \pm 60$ & $2050 \pm 60$ & 98 & $2.8 \times 10^{-3}$ & $4.0 \times 10^{-2}$ & 20 & $7.0 \times 10^{-2}$ \\
\hline
\end{tabular}


Table A1. Cont.

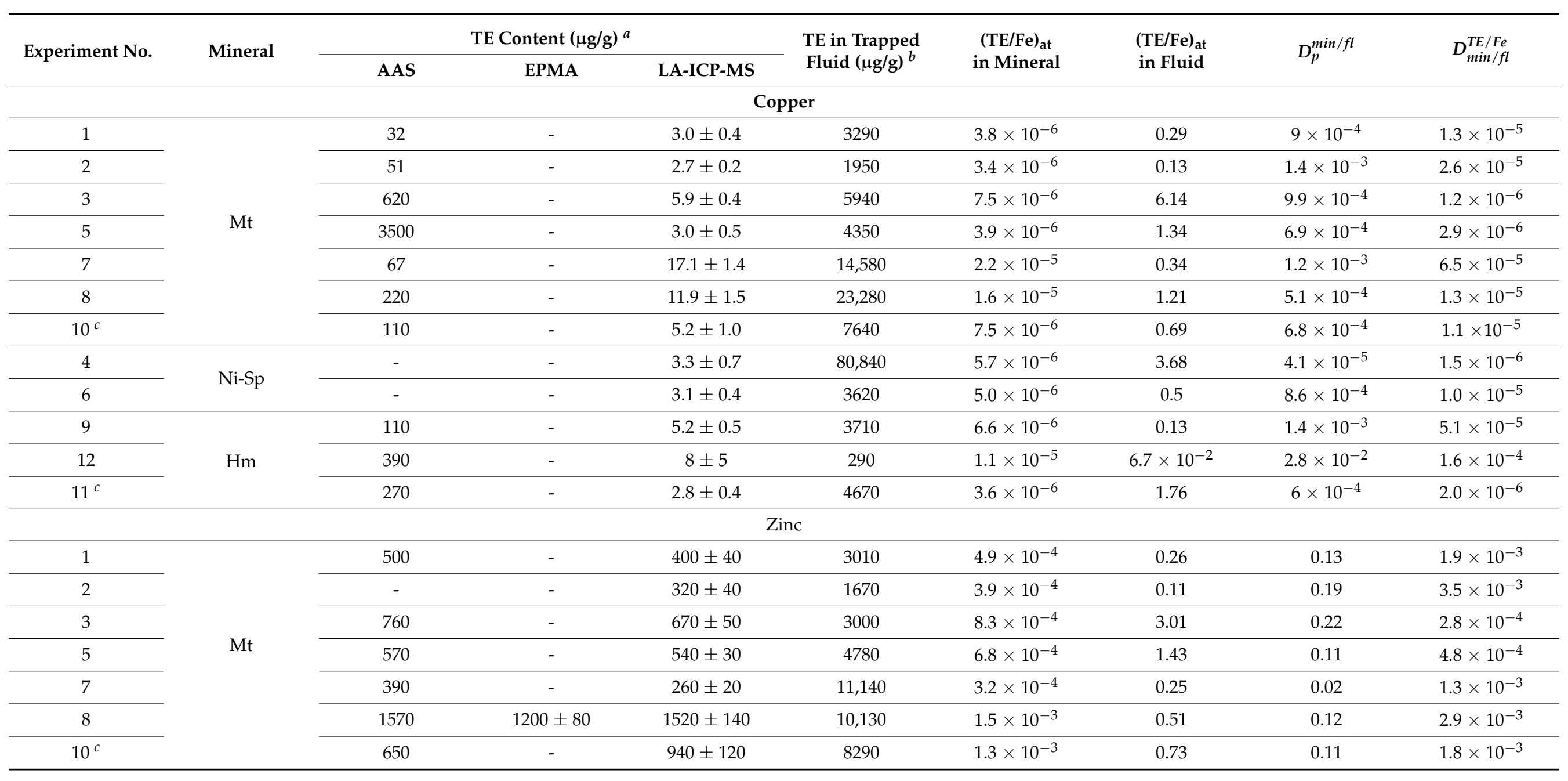


Table A1. Cont.

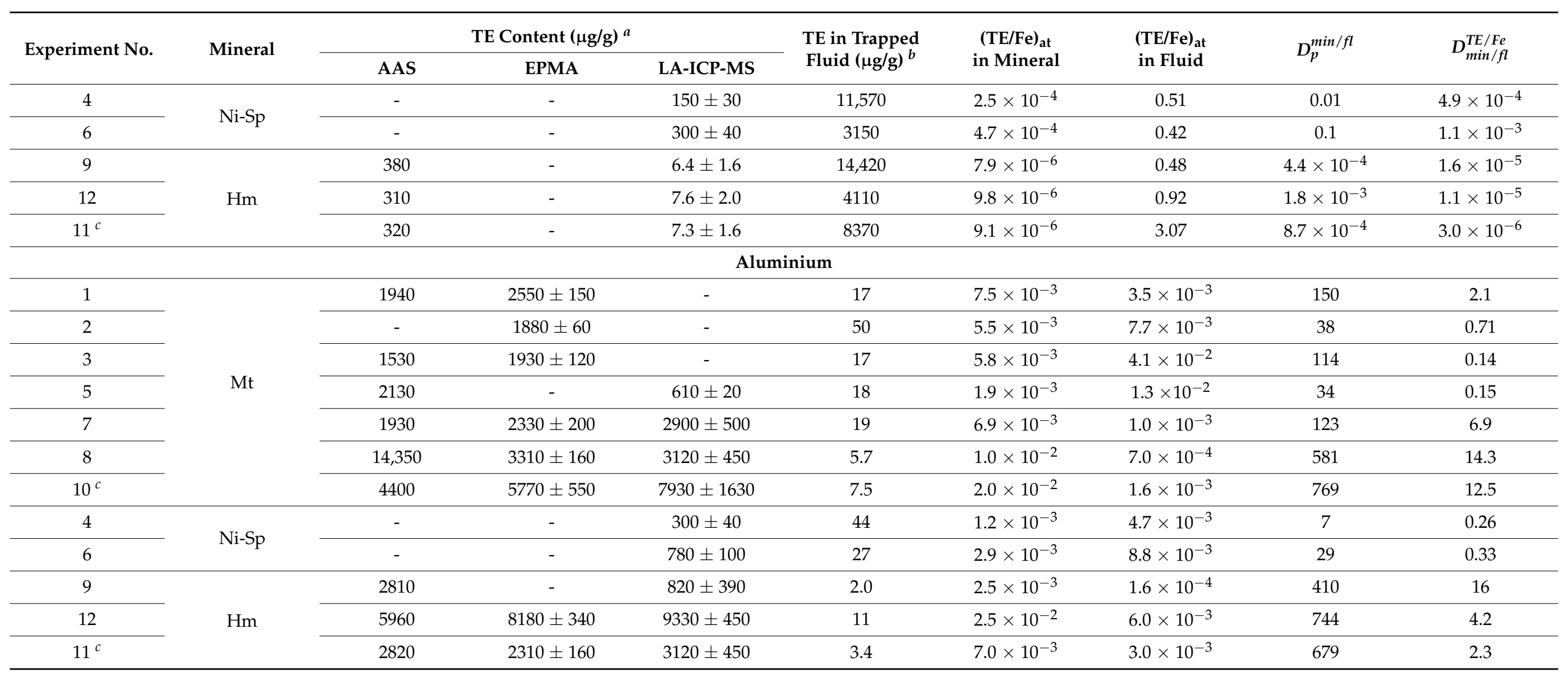


Table A1. Cont.

\begin{tabular}{|c|c|c|c|c|c|c|c|c|c|}
\hline \multirow{2}{*}{ Experiment No. } & \multirow{2}{*}{ Mineral } & \multicolumn{3}{|c|}{ TE Content $(\mu \mathrm{g} / \mathrm{g})^{a}$} & \multirow{2}{*}{$\begin{array}{l}\text { TE in Trapped } \\
\text { Fluid }(\mu \mathrm{g} / \mathrm{g})^{b}\end{array}$} & \multirow{2}{*}{$\begin{array}{c}(\mathrm{TE} / \mathrm{Fe})_{\mathrm{at}} \\
\text { in Mineral }\end{array}$} & \multirow{2}{*}{$\begin{array}{l}(\mathrm{TE} / \mathrm{Fe})_{a t} \\
\text { in Fluid }\end{array}$} & \multirow{2}{*}{$D_{p}^{\min / f l}$} & \multirow{2}{*}{$D_{\min / f l}^{T E / F e}$} \\
\hline & & AAS & EPMA & LA-ICP-MS & & & & & \\
\hline \multicolumn{10}{|c|}{ Manganese } \\
\hline $10^{c}$ & $\mathrm{Mt}$ & 1060 & $1690 \pm 100$ & $1630 \pm 120$ & 3550 & $2.8 \times 10^{-3}$ & 0.37 & 0.48 & $7.6 \times 10^{-3}$ \\
\hline 12 & \multirow{2}{*}{$\mathrm{Hm}$} & - & - & $14.4 \pm 1.3$ & 4300 & $2.2 \times 10^{-5}$ & 1.15 & $3.3 \times 10^{-3}$ & $1.9 \times 10^{-5}$ \\
\hline $11^{c}$ & & 320 & - & $50 \pm 2$ & 8080 & $7.4 \times 10^{-5}$ & 3.52 & $6.2 \times 10^{-3}$ & $2.1 \times 10^{-5}$ \\
\hline 9 & \multirow{3}{*}{$\mathrm{Hm}$} & 190 & - & $6.7 \pm 1.8$ & 2.7 & $1.0 \times 10^{-5}$ & $1.1 \times 10^{-4}$ & 2.5 & $9.1 \times 10^{-2}$ \\
\hline 12 & & 290 & - & $26 \pm 9$ & 1.5 & $4.2 \times 10^{-5}$ & $4.2 \times 10^{-4}$ & 17 & 0.1 \\
\hline $11^{c}$ & & 110 & - & $6.9 \pm 1.7$ & 0.7 & $1.1 \times 10^{-5}$ & $3.2 \times 10^{-4}$ & 9.9 & $3.4 \times 10^{-2}$ \\
\hline \multicolumn{10}{|c|}{ Vanadium } \\
\hline 12 & \multirow[b]{2}{*}{$\mathrm{Hm}$} & 22,450 & $25,310 \pm 660$ & $13,100 \pm 1040$ & 12 & $4.2 \times 10^{-2}$ & $3.5 \times 10^{-3}$ & 2110 & 12.0 \\
\hline $10^{c}$ & & 3740 & $3610 \pm 480$ & $2650 \pm 500$ & 35 & $6.5 \times 10^{-3}$ & $4.0 \times 10^{-3}$ & 103 & 1.6 \\
\hline
\end{tabular}

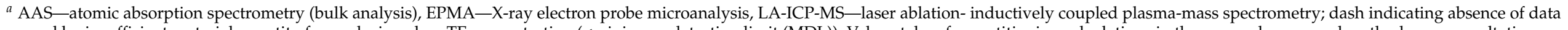

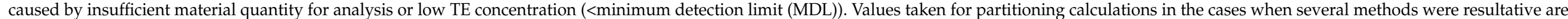

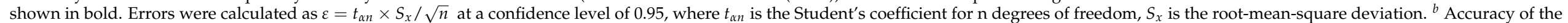
method is estimated as $+10 \%$ rel. ${ }^{c}$ Binary association $\mathrm{Mt}+\mathrm{Hm}$. 


\section{References}

1. Canil, D.; Grondahl, C.; Lacourse, T.; Pisiak, L.K. Trace elements in magnetite from porphyry Cu-Mo-Au deposits in British Columbia, Canada. Ore Geol. Rev. 2016, 72, 1116-1128. [CrossRef]

2. Nadoll, P.; Mauk, J.L.; Hayes, T.S.; Koenig, A.E.; Box, S.E. Element partitioning in magnetite under low-grade metamorphic conditions-A case study from the Proterozoic Belt Supergroup, USA. Eur. J. Mineral. 2017, 29, 795-805. [CrossRef]

3. Wen, G.; Li, J.W.; Hofstra, A.H.; Koenig, A.E.; Lowers, H.A.; Adams, D. Hydrothermal reequilibration of igneous magnetite in altered granitic plutons and its implications for magnetite classification schemes: Insight from the Handan-Xingtai iron district, North China Craton. Geochim. Cosmochim. Acta 2017, 213, 255-270. [CrossRef]

4. Dare, S.A.S.; Barnes, S.-J.; Beaudoin, G. Did the massive magnetite "lava flows" of El Laco (Chile) form by magmatic or hydrothermal processes? New constraints from magnetite composition by LA-ICP-MS. Miner. Depos. 2015, 50, 607-617. [CrossRef]

5. Knipping, J.L.; Bilenker, L.D.; Simon, A.C.; Reich, M.; Barra, F.; Deditius, A.P.; Wälle, M.; Heinrich, C.A.; Holtz, F.; Munizaga, R. Trace elements in magnetite from massive iron oxide-apatite deposits indicate a combined formation by igneous and magmatichydrothermal processes. Geochim. Cosmochim. Acta 2015, 171, 15-38. [CrossRef]

6. Chen, W.T.; Zhou, M.-F.; Gao, J.-F.; Hu, R. Geochemistry of magnetite from Proterozoic Fe-Cu deposits in the Kangdian metallogenic province, SW China. Miner. Depos. 2015, 50, 795-809. [CrossRef]

7. Verdugo-Ihl, M.R.; Ciobanu, C.L.; Cook, N.J.; Ehrig, K.J.; Courtney-Davies, L.; Gilbert, S. Textures and U-W-Sn-Mo signatures in hematite from the Olympic Dam Cu-U-Ag-Au deposit, South Australia: Defining the archetype for IOCG deposits. Ore Geol. Rev. 2017, 91, 173-195. [CrossRef]

8. Verdugo-Ihl, M.R.; Ciobanu, C.; Cook, N.J.; Ehrig, K.; Slattery, A.; Courtney-Davies, L. Trace-element remobilisation from $\mathrm{W}-\mathrm{Sn}-\mathrm{U}-\mathrm{Pb}$ zoned hematite: Nanoscale insights into a mineral geochronometer behaviour during interaction with fluids. Miner. Mag. 2020, 84, 502-516. [CrossRef]

9. Dupuis, C.; Beaudoin, G. Discriminant diagrams for iron oxide trace element fingerprinting of mineral deposit types. Miner. Depos. 2011, 46, 319-335. [CrossRef]

10. Dare, S.A.S.; Barnes, S.-J.; Beaudoin, G.; Méric, J.; Boutroy, E.; Potvin-Doucet, C. Trace elements in magnetite as petrogenetic indicators. Miner. Depos. 2014, 49, 785-796. [CrossRef]

11. Eliopoulos, D.G.; Economou-Eliopoulos, M. Trace element distribution in magnetite separates of varying origin: Genetic and exploration significance. Minerals 2019, 9, 759. [CrossRef]

12. Huang, X.-W.; Zhou, M.-F.; Qiu, Y.-Z.; Qi, L. In-situ LA-ICP-MS trace elemental analyses of magnetite: The Bayan Obo Fe-REE-Nb deposit, North China. Ore Geol. Rev. 2015, 65, 884-899. [CrossRef]

13. Huang, X.-W.; Zhou, M.-F.; Qi, L.; Gao, J.-F.; Wang, Y.-W. Re-Os isotopic ages and chemical composition of magnetite from the Cihai magmatic-hydrothermal Fe deposit, NW China. Miner. Depos. 2013, 48, 925-946. [CrossRef]

14. Nadoll, P.; Angerer, T.; Mauk, J.L.; French, D.; Walshe, J. The chemistry of hydrothermal magnetite: A review. Ore Geol. Rev. 2014, 61, 1-32. [CrossRef]

15. Wu, C.; Chen, H.; Hong, W.; Li, D.; Liang, P.; Fang, J.; Zhang, L.; Lai, C. Magnetite chemistry and implications for the magmatichydrothermal ore-forming process: An example from the Devonian Yuleken porphyry Cu system, NW China. Chem. Geol. 2019, 522, 1-15. [CrossRef]

16. Ilton, E.S.; Eugster, H.P. Base metal exchange between magnetite and a chloride-rich hydrothermal fluid. Geochim. Cosmochim. Acta 1989, 53, 291-301. [CrossRef]

17. Tauson, V.L.; Lipko, S.V.; Smagunov, N.V.; Kravtsova, R.G. Trace element partitioning dualism under mineral-fluid interaction: Origin and geochemical significance. Minerals 2018, 8, 282. [CrossRef]

18. Sidhu, P.S.; Gilkes, R.J.; Posner, A.M. The synthesis and some properties of Co, Ni, Zn, Cu, Mn and Cd substituted magnetites. J. Inorg. Nucl. Chem. 1978, 40, 429-435. [CrossRef]

19. Deditius, A.P.; Reich, M.; Simon, A.C.; Suvorova, A.; Knipping, J.; Roberts, M.P.; Rubanov, S.; Dodd, A.; Saunders, M. Nanogeochemistry of hydrothermal magnetite. Contrib. Mineral. Petrol. 2018, 173, 1-20. [CrossRef]

20. Yin, S.; Wirth, R.; Ma, C.; Xu, J. The role of mineral nanoparticles at a fluid-magnetite interface: Implications for trace-element uptake in hydrothermal systems. Am. Mineral. 2019, 104, 1180-1188. [CrossRef]

21. Chernyshev, L.V. On the theory of hydrothermal equilibria of minerals of variable composition. Geokhimiya 1980, 6, 787-797. (In Russian)

22. Chernyshev, L.V. Minerals of varying composition as indicators of the chemical evolution of hydrothermal solutions. In Physicochemical Models of Petrogenesis and Ore Formation; Nauka: Novosibirsk, Russia, 1984; pp. 5-9. (In Russian)

23. Urusov, V.S. Energetic formulation of the problem of equilibrium co-crystallization from water solutions. Geokhimiya 1980, 5, 627-644. (In Russian)

24. Gheletiy, V.F.; Chernyshev, L.V.; Pastushkova, T.M. Study of equilibria of solid-phases of the PbS-CdS system with water-salt solutions under high temperatures and pressure. Geokhimiya 1981, 10, 1463-1481. (In Russian)

25. Geletiy, V.F.; Pastushkova, T.M. Study of cadmium, manganese and zinc partition between lead sulfide and aqueous-salt solutions. In Physicochemical Models of Petrogenesis and Ore Formation; Nauka: Novosibirsk, Russia, 1984; pp. 9-21. (In Russian)

26. Tauson, V.L.; Smagunov, N.V.; Lipko, S.V. Using cocrystallization coefficients of isomorphous admixtures for determination of element concentrations in ore-forming solutions (by the example of Mn/Fe ratio in magnetite). Russ. Geol. Geophys. 2015, 56, 1128-1132. [CrossRef] 
27. Tauson, V.L.; Smagunov, N.V.; Lipko, S.V. Cocrystallization coefficients of Cr, V, and Fe in hydrothermal ore systems (from experimental data). Russ. Geol. Geophys. 2017, 58, 949-955. [CrossRef]

28. Tauson, V.L. Gold solubility in the common gold-bearing minerals: Experimental evaluation and application to pyrite. Eur. J. Mineral. 1999, 11, 937-947. [CrossRef]

29. Lipko, S.; Tauson, V.; Bychinskii, V. Gold partitioning in a model multiphase mineral-hydrothermal fluid system: Distribution coefficients, speciation and segregation. Minerals 2020, 10, 890. [CrossRef]

30. Tauson, V.L.; Babkin, D.N.; Pastushkova, T.M.; Akimov, V.V.; Krasnoshchekova, T.S.; Lipko, S.V.; Belozerova, O.Y. Dualistic distribution coefficients of elements in the system mineral-hydrothermal solution. II. Gold in magnetite. Geochem. Int. 2012, 50, 227-245. [CrossRef]

31. Ridgway, S.; Appleton, S.D.; Levinson, A.A. Ammonium geochemistry in mineral exploration-A comparison of results from American cordilleras and southwest Pacific. Appl. Geochem. 1990, 5, 475-489. [CrossRef]

32. Simpson, M.P. Hyperspectral (SWIR) characterisation of alteration at the Wharekirauponga epithermal Au-Ag prospect, Hauraki Goldfield, New Zealand. In Proceedings of the 51st Australasian Institute of Mining and Metallurgy New Zealand Branch Annual Conference, Tauranga, New Zealand, 17-18 September 2019; pp. 287-293.

33. Tauson, V.L.; Babkin, D.N.; Pastushkova, T.M.; Smagunov, N.V.; Lipko, S.V.; Voronova, I.Y.; Men'shikov, V.I.; Bryanskii, N.V.; Arsent'ev, K.Y. Dualistic distribution coefficients of trace elements in the system mineral-hydrothermal solution. III. Precious metals (Au and $\mathrm{Pd}$ ) in magnetite and manganmagnetite. Geochem. Int. 2016, 54, 149-166. [CrossRef]

34. Liang, X.; Zhong, Y.; Zhu, S.; He, H.; Yuan, P.; Zhu, J.; Jiang, Z. The valence and site occupancy of substituting metals in magnetite spinel structure $\mathrm{Fe}_{3-\mathrm{x}} \mathrm{M}_{\mathrm{x}} \mathrm{O}_{4}(\mathrm{M}=\mathrm{Cr}, \mathrm{Mn}, \mathrm{Co}$ and $\mathrm{Ni})$ and their influence on thermal stability: An XANES and TG-DSC investigation. Solid State Sci. 2013, 15, 115-122. [CrossRef]

35. Wells, M.A.; Fitzpatrick, R.W.; Gilkes, R.J. Thermal and mineral properties of Al-, Cr-, Mn-, Ni- and Ti-substituted goethite. Clays Clay Miner. 2006, 54, 176-194. [CrossRef]

36. Tauson, V.L.; Pastushkova, T.M.; Babkin, D.N.; Krasnoshchekova, T.S.; Lustenberg, E.E. The effect of the crystal size in sample on the trace-element concentration. Russ. Geol. Geophys. 2010, 51, 764-773. [CrossRef]

37. Chou, I.-M.; Eugster, H.P. Solubility of magnetite in supercritical chloride solutions. Amer. J. Sci. 1977, 277, 1296-1314. [CrossRef]

38. Chudnenko, K.V. Thermodynamic Modeling in Geochemistry: Theory, Algorithms, Software, Applications; Geo Publusher: Novosibirsk, Russia, 2010. (In Russian) 